\title{
Internationalization of Tourism Destinations: Networking systems management
}

\author{
Maria do Rosário Mira \\ Polytechnic Institute of Coimbra, Coimbra, Portugal \\ Zélia de Jesus Breda \\ University of Aveiro, Aveiro, Portugal
}

Received: 22 July 2021. Revision received: 17 September 2021. Accepted: 16 November 2021

\begin{abstract}
This paper aims to fill a gap in the existing research about the internationalization of tourism destinations through a systematic review of the literature focusing on publications presented between 2007 and 2017. The research followed the assumptions of the non-probabilistic snowball sampling technique. In addition, the computer programs VosViewer, for bibliometric analysis, and NVivo 10, for content analysis were used. Tourism destinations' internationalization is a combination of: (i) integration of organizational interest with stakeholders' interests; (ii) understanding that what moves these elements are endogenous and exogenous business opportunities; (iii) integrating external opportunities in the destination by aligning them with its territorial identity; (iv) achieving coherence between the previous three components through the implementation of a governance model; (v) a governance model that facilitates the destination's organization by conciliating interests, resources and opportunities; (vi) and the DMOs that coordinate the dynamics generated between the elements of this system, making it possible to organize the supply following its territorial identity. The internationalization process of tourism destinations highlights factors different from the internationalization of companies. In the first scenario, politics, planning, and territory internationalization strategies should target different kinds of reflections according to the level of intervention (local, regional, national or international). In the second, it is essential that supply is aware of investment opportunities abroad, financial packages to support businesses, innovation, and entrepreneurship. The current period exposed the fragility of the tourism sector and how external threats can influence it. Thinking about the internationalization of tourism destinations shows how important it is to organize the tourism offer in accordance with the challenges the sector faces, at the same time as explaining the role of DMOs. Until now, this theme has been mainly studied from the perspective of demand, creating a gap in the existing knowledge about the organizational systems.
\end{abstract}

Key Words: Internationalization, tourism destinations, systems innovation, territory, product, governance, DMOs.

JEL Classification: Z3; Z32

Reference: Mira, M.R., Breda, Z.J. (2021). Internationalization of Tourism Destinations: Networking systems management. Journal of Tourism and Services, 23(12), 105-131. doi: 10.29036/jots.v12i23.285

\section{Introduction}

Internationalizing tourism destinations is a key issue in tourism, reinforced by the current pandemic. Studying the effects of COVID 19 on the way tourism is defined, planned, organized, innovated, and internationalized has been a priority (Cave and Dredge, 2020; Han, 2021; Kuhzady, Olya, \& Farmaki, 2021; Marek, 2021; Zhang, \& Wang, 2020). The first reference to 'international tourism 


\section{JOURNAL OF TOURISM AND SERVICES}

Issue 23, volume 12, ISSN 1804-5650 (Online)

www.jots.cz

destinations' appeared about 20 years ago (Komorowski, 2000), in the literature review format and covers the period from 1992 to 1997. This study focused on the development of the market economy in Poland and its impact on the internationalization of cities in this country, resulting from the opening to international connections and contacts. It concludes that the potential for internationalization may depend on geographic location, cultural wealth and, above all, on the way in which political, national and local authorities face this process of opening to the outside world (Komorowski, 2000).

In the following decade there was no research on this topic, with renewed attention from the scientific community in 2007. The concept of internationalization in tourism, up to this point, does not integrate the analysis of the tourism system, nor does it address the internationalization of destinations, focusing essentially on the process of internationalization of companies. That research on internationalization in tourism has focused on economics and business, forgetting behavioral, political and geographic approaches, which are fundamental to the analysis of the context and tourist flows. Considering the internationalization of destinations implies adopting an angle that is still little explored and that justifies the research carried out (Yeoman \& Beeton, 2014).

For that reason, we carried out a systematic literature review (Gomezelj, 2016), which clarifies the concept and the factors that explain it. Publications written in Spanish, French, English and Portuguese between 2007 and 2017 were selected. It is necessary to distinguish the process of internationalization of destinations from that of companies. In the first, it is the policies, planning and internationalization strategies of the territory that should be the object of differentiated reflection, depending on the level of intervention (local, regional, national or international). Innovation, knowledge and network governance are fundamental conditions to consolidate this process (Grasso, 2014). This way of looking at destinations triggers change processes, both within organizations and in the collaborative relationship between stakeholders. In companies' internationalization, investment opportunities abroad, financial conditions to support business, innovation and entrepreneurship are highlighted (Onuferová, Čabinová \& Vargová, 2020).

The different theoretical options that contextualize the issue of internationalization of destinations demonstrate the relevance of producing knowledge in this scientific domain, considering that: i) the internationalization of destinations results from the territory's economy, framed in a systemic perspective that promotes competitiveness, networks and governance (Volgger \& Pechlaner, 2014;); ii) the internationalization of destinations is related to the identity of the destination associated with the capacity of the DMOs to reinforce this distinctive capacity of territories (Badulescu, Hoffman, Badulescu \& Simut, 2016; Blasco, Guia \& Prats, 2014b; Bohlin, Brandt \& Elbe, 2016; Booyens, 2016; Booyens \& Rogerson, 2015; Brouder \& Ioannides, 2014; Clavé \& Wilson, 2017; Escach \& Vaudor, 2014; Getz \& Page, 2016; Makkonen \& Rohde, 2016; Makkonen \& Weidenfield, 2016; Makkonen \& Williams, 2016; Sakharchuk, Kharitonova, Krivosheeva \& Ilkevich, 2013; Szytniewski, Spierings \& van der Velde, 2017; Vermeulen, 2015; Vodeb \& Rudež, 2016; Volgger \& Pechlaner, 2015; Więckowski \& Cerić, 2016). The main issue is to understand whether the internationalization of destinations, from the point of view of supply, is influenced by the systemic perspective of tourism and whether the Destination Management Organizations (DMOs) ensure the functioning of this system. It is observed that the clarification of this issue is a current concern, both of the scientific community and of tourism professionals, who predominantly frame it within the scope of the knowledge economy or economic geography (Volgger \& Pechlaner, 2014).

In summary, the internationalization of destinations is based on four components: territory, product, governance model and DMOs (Mira \& Breda, 2019). The first two are considered the structuring elements of the destination, insofar as they allow the geographical identification of the territory and emphasize its identity, giving rise to two processes: mapping and positioning of the destination. The governance model and DMOs emerge as the integrating elements, because they promote collaborative management of the networked stakeholders and give unity to this system (Fernando, 2020). 


\section{JOURNAL OF TOURISM AND SERVICES}

Issue 23, volume 12, ISSN 1804-5650 (Online)

www.jots.cz

This article contributes to the clarification of the construct' internationalization of destinations', which is fundamental in the recovery of tourism in the post-COVID period. It presents a conceptual model that emphasizes the systemic perspective of destinations and systematizes the key factors and dimensions in this process.

\section{Literature review}

The theoretical models that explain the processes of internationalization of tourism destinations are not homogeneous and there are still notable differences between the various authors in the specialty. The economic current is predominant, as it is in this domain of knowledge that the study of this issue arises, due to the need to capture new markets and the consolidation of business. However, an investigation into the internationalization of tourism destinations requires a broader and more comprehensive attention to this concept that will allow a better explanation of this phenomenon in light of the systemic approach to tourism. The relationship between internationalization of destinations and the dimensions that define this construct ('Territory', 'Product', Governance' and 'DMOs'), reveals a complex system of multiple variables that influence this process. They differ depending on the dimension under analysis. The economic perspective of internationalization of tourism destinations highlights the importance of territories by focusing on the social, economic, cultural and political contexts. In this perspective, promoting the internationalization of destinations implies the active involvement of government structures, as it is economic, social, educational and environmental policies that favor the competitive capacity of regions. However, the territory is a system made up of people, where characteristics of the regions, borders and available resources condition destinations' internationalization process. The multiplicity of elements that are interconnected justifies the specification of the variables that are influenced, directly or not, by the capacity of destinations to internationalize. The mediating variables of the 'Territory' dimension are specified in Table 1.

Table 1. Mediating variables of the association between 'Internationalization of destinations' and 'Territory'

\begin{tabular}{|c|c|c|}
\hline $\begin{array}{l}\text { MEDIATING } \\
\text { VARIABLE }\end{array}$ & SPPECIFICATION & AUTHORS \\
\hline \multirow{4}{*}{ Actors } & Public & Badulescu et al. (2016); Makkonen and Williams (2016); Więckowski and Cerić (2016) \\
\hline & Private & Badulescu et al. (2016); Makkonen and Williams (2016); Więckowski and Cerić (2016) \\
\hline & Residents & Badulescu et al. (2016); Freestone (2007); Makkonen and Williams (2016) \\
\hline & Visitors & Bohlin et al. (2016); Sanz-Ibáñez and Clavé (2016); Więckowski and Cerić (2016) \\
\hline \multirow{5}{*}{ Typology } & Identity & $\begin{array}{l}\text { Blasco et al. (2014b); Nilsson et al. (2010); Sarasa (2015); Sertakova et al. (2016); } \\
\text { Soares et al. (2015); Scuttari et al. (2016) }\end{array}$ \\
\hline & Knowledge & $\begin{array}{l}\text { Badulescu et al. (2016); Bannò et al. (2015); De Noni et al. (2014); Makkonen and } \\
\text { Williams (2016) }\end{array}$ \\
\hline & Quality of life & Bohlin et al. (2016); De Noni et al. (2014); Freestone (2007) \\
\hline & Opportunities & $\begin{array}{l}\text { Badulescu et al. (2016); Bholin et al. (2016) Blasco et al. (2014a); Timothy et al. (2016); } \\
\text { Vodeb and Rudež (2016); Volgger and Pechlaner (2015) }\end{array}$ \\
\hline & Business & $\begin{array}{l}\text { Badulescu et al. (2016); Bannò et al. (2015); Bholin et al. (2016); Blasco et al. (2014a); } \\
\text { Timothy et al. (2016); Vodeband Rudež (2016); Volgger and Pechlaner (2015) }\end{array}$ \\
\hline \multirow{3}{*}{ Borders } & Geographic & Escach and Vaudor (2014); Prokkola and Lois (2016); Varró, (2016) \\
\hline & Cultural & Blasco (2014b); Brouder and Ioannides (2014) \\
\hline & Administrative & Badulescu et al. (2016); Blasco et al. (2014b); Sarasa (2015) \\
\hline \multirow{2}{*}{ Resources } & Natural & Timothy et al. (2016); Weidenfeld (2013) \\
\hline & Cultural & Timothy et al. (2016); Szytniewski et al. (2017); Weidenfeld (2013) \\
\hline
\end{tabular}




\begin{tabular}{l|l|l}
\hline \hline & Financial & $\begin{array}{l}\text { Bannò et al. (2015); Bholin et al. (2016); Badulescu, et al. (2016); Volgger and } \\
\text { Pechlaner (2015) }\end{array}$ \\
\cline { 2 - 3 } & Support & $\begin{array}{l}\text { Bernabé and Hernández (2016); Bohlin et al. (2016); Ferdinand and Williams (2013); } \\
\text { Getz and Page (2016); Rovira (2016); Wieckowski and Cerić (2013); Timothy et al. }\end{array}$ \\
\hline \hline
\end{tabular}

Source: own research

A tourism destination results from the combination of products, services and experiences, within a geographical area, supported by a supply and demand management model, capable of maximizing the benefits of the interested parties. For this, the economic activity of the territories needs to be supported by strategic guidelines that promote the combined management of resources. This approach reinforces the importance of organized collective action. The network organization of stakeholders, knowledge and innovation that contribute to the construction of a common identity, which supports the destination's brand, is highlighted. From this perspective, internationalizing destinations implies managing territories as regional systems of innovation. It is essential to motivate stakeholders to network, innovate in products and develop leadership and change management skills necessary to the governance of the destination. The governance of this system poses questions to companies, public entities and stakeholders in general, namely: (i) it is important to develop systems for evaluating results, leading to the preparation of strategic plans in coordination with the trends of the environment and the sector, which allow us to respond to local and international challenges; (ii) it is essential to prepare companies to coordinate their activity towards the management of knowledge and innovation, supported by territorial identity; (iii) it is urgent to characterize both existing and potential resources, coordinate the action of stakeholders, manage the destination's marketing, create a coherent and homogeneous image and disseminate business and regional development opportunities. To this end, it is essential to implement local self-governance systems. What has been explained so far suggests that the destination's strategic plan needs to take into account a multiplicity of elements that affect the internationalization process. Tables 2, 3 and 4 systematize the variables that mediate the internationalization of destinations, in terms of product and governance model.

The product is associated with different variables, depending on whether the composite product (destination) or tourism products is considered in isolation. What transforms a region into an attractive tourism destination are the experiences that the visitor can have, the production of knowledge and its transfer to stakeholders, innovation with an endogenous basis and marketing (Table 2).

Table 2. Mediating variables of the association between 'Internationalization of destinations' and 'Composite Product (Destinations)'

\begin{tabular}{|c|c|c|}
\hline $\begin{array}{l}\text { MEDIATING } \\
\text { VARIABLE }\end{array}$ & SPECIFICATION & AUTHORS \\
\hline Attractiveness & $\begin{array}{l}\text { Tourism } \\
\text { experience }\end{array}$ & $\begin{array}{l}\text { Badulescu et al. (2016); Bernabé and Hernández (2016); Bohlin et al. (2016); Booyens } \\
\text { and Rogerson (2015, 2016); Clavé and Wilson (2017); Sanz-Ibáñez and Clavé (2016); } \\
\text { Sarasa (2015); Soares et al. (2015); Szytniewski et al. (2017); Rovira (2016); } \\
\text { Vermeulen (2016); Vodeb and Rudež (2016) }\end{array}$ \\
\hline Knowledge & $\begin{array}{l}\text { Knowledge } \\
\text { transfer }\end{array}$ & $\begin{array}{l}\text { Booyens (2016); Booyens and Rogerson (2015, 2016); Makkonen and Rhode (2016); } \\
\text { Makkonen and Weidenfeld (2016); Sarasa (2015); Volgger and Pechlaner (2015) }\end{array}$ \\
\hline Innovation & $\begin{array}{l}\text { Endogenous } \\
\text { products }\end{array}$ & $\begin{array}{l}\text { Booyens (2016); Booyens and Rogerson (2015); Clavé and Wilson (2017); De Noni } \\
\text { et al. (2014); Makkonen and Rhode (2016); Sarasa (2015); Soares et al. (2015); } \\
\text { Szytniewski et al. (2017); Rovira (2016); Vodeb and Rudandž (2016) }\end{array}$ \\
\hline \multirow[b]{2}{*}{ Marketing } & Brand & $\begin{array}{l}\text { Brouder and Ioannides (2014); Blasco et al. (2014b); Nilsson et al. (2010); Rovira } \\
\text { (2016); Sertakova et al. (2016); Timothy et al. (2016) }\end{array}$ \\
\hline & Markets & $\begin{array}{l}\text { Badulescu et al. (2016); Bernabé and Hernández (2016); Bohlin et al. (2016); Booyens } \\
\text { and Rogerson (2015, 2016); Clavé and Wilson (2017); Sanz-Ibáñez and Clavé (2016); } \\
\text { Sarasa (2015); Soares et al. (2015); Szytniewski et al. (2017); Rovira (2016); } \\
\text { Vermeulen (2016); Vodeb and Rudež (2016) }\end{array}$ \\
\hline
\end{tabular}




\section{JOURNAL OF TOURISM AND SERVICES}

Issue 23, volume 12, ISSN 1804-5650 (Online)

www.jots.cz

Source: own research

In turn, the tourism product depends on the entrepreneurial capacity of human resources and the satisfaction of visitors and residents with tourism in the region. A key aspect is the use of new technologies in the production, marketing and promotion of tourism products (Table 3 ).

Table 3. Mediating variables of the association between 'Internationalization of destinations' and 'Product'

\begin{tabular}{|c|c|c|}
\hline $\begin{array}{l}\text { MEDIATING } \\
\text { VARIABLE }\end{array}$ & SPECIFICATION & AUTHORS \\
\hline \multirow{3}{*}{ Entrepreneurship } & Business & $\begin{array}{l}\text { Blasco et al. (2014b); Bohlin et al. (2016); De Noni et al. (2014); Getz and Page } \\
\text { (2016) }\end{array}$ \\
\hline & Opportunities & Bannò et al. (2015); De Noni et al. (2014); Timothy et al. (2016) \\
\hline & Investment & $\begin{array}{l}\text { Booyens (2016); Vermeulen (2016); Vodeb and Rudež (2016); Volgger and } \\
\text { Pechlaner (2015) }\end{array}$ \\
\hline \multirow{3}{*}{ Quality } & Results assessment & Bernabé and Hernández (2016); Sarasa (2015); Soares et al. (2015) \\
\hline & $\begin{array}{l}\text { Tourists' } \\
\text { satisfaction }\end{array}$ & $\begin{array}{l}\text { Blasco et al. (2014b); Sanz-Ibánez and Clavé (2016); Volgger and Pechlaner (2015); } \\
\text { Weidenfeld (2013) }\end{array}$ \\
\hline & $\begin{array}{l}\text { Residents' } \\
\text { satisfaction }\end{array}$ & De Noni et al. (2014); Rovira (2016); Weidenfeld (2013) \\
\hline \multirow{2}{*}{ Human resources } & Training & $\begin{array}{l}\text { Badulescu et al. (2016); De Noni et al. (2014); Ferdinand and Williams (2013); } \\
\text { Makkonen and Williams (2016); Sakharchuk et al. (2013) }\end{array}$ \\
\hline & Qualification & $\begin{array}{l}\text { Badulescu et al. (2016); De Noni et al. (2014); Ferdinand and Williams (2013); } \\
\text { Makkonen and Williams (2016); Sakharchuk et al. (2013) }\end{array}$ \\
\hline \multirow{3}{*}{$\begin{array}{l}\text { Technological } \\
\text { resources }\end{array}$} & Production & $\begin{array}{l}\text { Booyens (2016); Brouder and Ioannides (2014); Clavé and Wilson (2017); } \\
\text { Vodeband Rudež (2016); Nilsson et al. (2010) }\end{array}$ \\
\hline & Promotion & $\begin{array}{l}\text { Booyens (2016); Boyens and Rogerson (2016); Clavé and Wilson (2017); Escah } \\
\text { and Vaudor (2014); Vodeband Rudež (2016) }\end{array}$ \\
\hline & Commercialization & $\begin{array}{l}\text { Blasco et al. (2014b); Bohlin et al. (2016); Blasco (2014); Sanz-Ibáñez and Clavé } \\
\text { (2016); Weidenfeld (2013) }\end{array}$ \\
\hline
\end{tabular}

Source: own research

Collaboration between stakeholders organized in a network, planning, and evaluating results give strength to governance models and facilitate the internationalization of destinations. Governance that stimulates knowledge, innovation, and complementarity in tourism is presented in Table 4.

Table 4. Mediating variables of the association between 'Internationalization of destinations' and 'Governance'

\begin{tabular}{|c|c|c|}
\hline $\begin{array}{l}\text { MEDIATING } \\
\text { VARIABLE }\end{array}$ & SPECIFICATION & AUTHORS \\
\hline Assessment & Destination outputs & $\begin{array}{l}\text { Badulescu et al (2016); Bholin et al. (2016); Bannò et al. (2015); } \\
\text { Booyens and Rogerson (2015); Getz and Page (2016) }\end{array}$ \\
\hline \multirow{3}{*}{ Collaboration } & $\begin{array}{l}\text { Stakeholder involvement in } \\
\text { destination leadership }\end{array}$ & Farmaki (2015); Vodeb and Rudež (2016) \\
\hline & $\begin{array}{l}\text { Stakeholder involvement in } \\
\text { destination decisions }\end{array}$ & $\begin{array}{l}\text { Badulescu et al. (2016); Bernabé and Hernández (2016); Bohlin et } \\
\text { al. (2016); Booyens (2016); Brouder and Ioannides (2014); De } \\
\text { Noni et al. (2014); Escah and Vaudor (2014); Farmaki (2015); } \\
\text { Sanz-Ibáñez and Clavé (2016); Sarasa (2015); Vodeb and Rudež } \\
\text { (2016); Weidenfeld (2013) }\end{array}$ \\
\hline & $\begin{array}{l}\text { Involvement of residents in the } \\
\text { destination project }\end{array}$ & $\begin{array}{l}\text { Badulescu et al. (2016); Booyens and Rogerson (2015); Makkonen } \\
\text { and Rhode (2016); Sarasa (2015); Soares et al. (2015); Vermeulen } \\
\text { (2015) }\end{array}$ \\
\hline
\end{tabular}




\begin{tabular}{|c|c|c|}
\hline & $\begin{array}{l}\text { Stakeholder involvement in human } \\
\text { resource training }\end{array}$ & Blasco et al (2014a); Weidenfeld (2013) \\
\hline & Resource sharing among stakeholders & $\begin{array}{l}\text { Booyens and Rogerson (2015); Soares et al. (2015); Todd, Leask } \\
\text { and Ensor (2017);Vermeulen (2015) }\end{array}$ \\
\hline & $\begin{array}{l}\text { Cultural proximity between } \\
\text { stakeholders }\end{array}$ & $\begin{array}{l}\text { Blasco et al (2014a); Booyens and Rogerson (2015); Todd, Leask } \\
\text { and Ensor (2017). }\end{array}$ \\
\hline \multirow{5}{*}{ Planning } & Destination project planning & $\begin{array}{l}\text { Booyens (2016);Booyens and Rogerson (2016); Clavé and Wilson } \\
\text { (2017); Escah and Vaudor (2014); Makkonen and Rhode (2016); } \\
\text { Makkonen and Weidenfel (2016) }\end{array}$ \\
\hline & $\begin{array}{l}\text { Public participation in defining } \\
\text { destination policies }\end{array}$ & $\begin{array}{l}\text { Booyens and Rogerson (2015); Makkonen and Rohde (2016); } \\
\text { Sertakova et al. (2016) }\end{array}$ \\
\hline & Network planning of the tourist offer & $\begin{array}{l}\text { Bernabé and Hernández (2016); Blasco et al. (2014a); Blasco et al. } \\
\text { (2014b); Escah and Vaudor (2014); Farmaki (2015) }\end{array}$ \\
\hline & Destination infrastructure planning & $\begin{array}{l}\text { Bernabé and Hernández (2016); Blasco et al. (2014a); Blasco et al. } \\
\text { (2014b); Escah and Vaudor (2014); Farmaki (2015) }\end{array}$ \\
\hline & $\begin{array}{l}\text { Policies for setting qualified human } \\
\text { resources }\end{array}$ & $\begin{array}{l}\text { Bernabé and Hernández (2016); Escach and Vaudor (2014); } \\
\text { Sarasa (2015) }\end{array}$ \\
\hline \multirow{7}{*}{ Networks } & Destination promotion networks & Rovira (2016); Sertakova et al. (2016) \\
\hline & Innovation networks & $\begin{array}{l}\text { Makkonen and Rhode (2016); Sanz-Ibáñez and Clavé (2016); } \\
\text { Scuttari et al. (2016); Sertakova et al. (2016) }\end{array}$ \\
\hline & Knowledge networks & $\begin{array}{l}\text { Sanz-Ibáñez and Clavé (2016); Sarasa (2015); Scuttari et al. (2016); } \\
\text { Sertakova et al. (2016) }\end{array}$ \\
\hline & International networks & Bohlin et al. (2016); Brouder and Ioannides (2014) \\
\hline & Inter-destination networks & $\begin{array}{l}\text { Blasco et al. (2014a); Bohlin et al. (2016); Farmaki (2015); } \\
\text { Ferdinand (2013); Makkonen and Rhode (2016) }\end{array}$ \\
\hline & Inter-organizational networks & $\begin{array}{l}\text { Blasco et al. (2014a); Bohlin et al. (2016); Clavé and Wilson (2017); } \\
\text { Farmaki (2015); Volgger and Pechlaner (2015) }\end{array}$ \\
\hline & Development networks & $\begin{array}{l}\text { Booyens (2016); Escah and Vaudor (2014); Booyens and } \\
\text { Rogerson }(2015,2016) ; \text { Volgger and Pechlaner (2015) }\end{array}$ \\
\hline
\end{tabular}

The existence of a transforming structure of individual initiatives and interests in regional objectives facilitates the management of the destination, as if it were a single organization, which is essential for the territories' competitive advantage. In this context, it is important to define the limits between the responsibility and internal action of organizations and those that must be managed at the destination level. DMOs can be an enabling and bridging element between the local, national and international levels, as well as between the public and private sectors. However, stimulating a learning culture, organized in a network, in a given territory, requires measuring results, evaluating decisions and rethinking strategies. Taking into account the above, it is understood that the role of DMOs in the internationalization of tourism destinations must take into account: (i) the facilitators as well as the different levels at which these variables have to be managed; (ii) the differentiated strategies and actions according to the nature and scope of the problems; (iii) the results intended to be achieved. In this sense, the explanation of these variables and associated approaches, represent a step forward in terms of clarifying this issue.Table 5 specifies the role of DMOs and their role in the management of this system, aligning the development of products with the identity of the territory. The need for a mobilizing structure for systems management within systems is stressed.

Table 5. Mediating variables of the association between 'Internationalization of destinations' and 'DMOs'

\begin{tabular}{c|c|c}
\hline $\begin{array}{c}\text { MEDIATING } \\
\text { VARIABLE }\end{array}$ & \multicolumn{1}{|c}{ SPECIFICATION } & \multicolumn{1}{|c}{ AUTHORS } \\
\hdashline $\begin{array}{c}\text { Governance } \\
\text { Model }\end{array}$ & Definition of target policies & $\begin{array}{l}\text { Badulescu et al. (2016); Booyens (2016); Makkonen and Williams } \\
(2016)\end{array}$ \\
\hline \hline
\end{tabular}




\begin{tabular}{|c|c|c|}
\hline & Destination project coordination & $\begin{array}{l}\text { Blasco et al. (2014a); Booyens (2016); Escah and Vaudor (2014); } \\
\text { Vodeb and Rudež (2016); Volgger and Pechlaner, 2015; Weidenfeld } \\
\text { (2013); Yeoman and Beeton (2014) }\end{array}$ \\
\hline & stakeholders' & $\begin{array}{l}\text { Booyens (2016); Makkonen and Rhode (2016); Sanz-Ibáñez and } \\
\text { Clavé (2016); Volgger and Pechlaner (2015) }\end{array}$ \\
\hline & Tourism services' coordination & Badulescu et al. (2016); Escah and Vaudor (2014); Farmaki (2015) \\
\hline & $\begin{array}{l}\text { Management marketing networks } \\
\text { of tourism products }\end{array}$ & $\begin{array}{l}\text { Badulescu et al. (2016); Bernabé and Hernández (2016); Escah and } \\
\text { Vaudor (2014); Farmaki (2015) }\end{array}$ \\
\hline & Change process management & $\begin{array}{l}\text { Booyens and Rogerson (2015); Brouder and Ioannides (2014); Soares } \\
\text { et al. (2015) }\end{array}$ \\
\hline & $\begin{array}{l}\text { Participation in investment } \\
\text { management at destination }\end{array}$ & $\begin{array}{l}\text { Badulescu et al. (2016); Bholin et al. (2016); Booyens (2016); Nilsson } \\
\text { et al. (2010) }\end{array}$ \\
\hline & $\begin{array}{l}\text { Budget management available for } \\
\text { destination tourism }\end{array}$ & $\begin{array}{l}\text { Blasco et al. (2014b); Bholin et al. (2016); Booyens (2016); Nilsson et } \\
\text { al. (2010) }\end{array}$ \\
\hline & Destination internationalization & $\begin{array}{l}\text { Makkonen and Rhode (2016); Weickowski and Cerić (2016); } \\
\text { Weidenfeld (2013); Yeoman and Beeton (2014) }\end{array}$ \\
\hline \multirow{8}{*}{$\begin{array}{c}\text { Product } \\
\text { Development }\end{array}$} & Integrated market management & Blasco et al. (2014b); Getz and Page (2016); Nilsson et al. (2010) \\
\hline & Integrated marketing management & $\begin{array}{l}\text { Blasco et al. (2014b); De Noni (2014); Sakharchuk et al. (2013); } \\
\text { Vermeulen (2016); Vodeb and Rudež (2016) }\end{array}$ \\
\hline & Human resources development & $\begin{array}{l}\text { De Noni et al. (2014); Ferdinand and Williams (2013); Sakharchuk et } \\
\text { al. (2013) }\end{array}$ \\
\hline & $\begin{array}{l}\text { Definition of working conditions in } \\
\text { tourism }\end{array}$ & $\begin{array}{l}\text { De Noni et al. (2014); Ferdinand and Williams (2013); Sakharchuk et } \\
\text { al. (2013) }\end{array}$ \\
\hline & $\begin{array}{l}\text { Tourism product innovation } \\
\text { management }\end{array}$ & $\begin{array}{l}\text { Bernabé and Hernández (2016); Blasco et al. (2014b); Booyens } \\
\text { (2016); Booyens and Rogerson (2016); Brouder and Ioannides (2014) }\end{array}$ \\
\hline & Knowledge management & $\begin{array}{l}\text { Bernabé and Hernández (2016); Blasco et al. (2014b); Booyens } \\
\text { (2016); Booyens and Rogerson (2016); Brouder and Ioannides (2014) }\end{array}$ \\
\hline & Investment fundraising & Bholin et al. (2016); Nilsson et al. (2010) \\
\hline & Destination promotion & Blasco et al. (2014b) \\
\hline \multirow{5}{*}{$\begin{array}{l}\text { Territory } \\
\text { Organization }\end{array}$} & Integrated resource management & $\begin{array}{l}\text { Badulescu et al. (2016); Makkonen and Weidenfeld (2016); Sanz- } \\
\text { Ibáñez and Clavé (2016); Sakharchuk et al. (2013); Vermeulen (2016); } \\
\text { Vodeb and Rudež (2016) }\end{array}$ \\
\hline & Risk management & Booyens and Rogerson (2015); Vodeb and Rudež (2016) \\
\hline & Opportunity management & $\begin{array}{l}\text { Booyens and Rogerson (2015); Sakharchuk et al. (2013); Vermeulen } \\
\text { (2016); Vodeb and Rudež (2016) }\end{array}$ \\
\hline & Territory planning & $\begin{array}{l}\text { Badulescu et al. (2016); Freestone (2007; Nilsson et al. (2010); Soares } \\
\text { et al. (2015); Rovira (2016) }\end{array}$ \\
\hline & Destination's identity promotion & $\begin{array}{l}\text { Blasco et al. (2014a); Booyens (2016); Escah and Vaudor (2014); } \\
\text { Makkonen and Rhode (2016); Vodeb and Rudež (2016); Weidenfeld } \\
\text { (2013); Yeoman and Beeton (2014) }\end{array}$ \\
\hline
\end{tabular}

It was considered that the organization of the territory as learning and innovation systems, contributes to the reinforcement of its identity, provided that such a system encourages the emergence of learning communities, values the training of human resources and is supported by research produced on tourism. These facilitators, in turn, should emphasize the uniqueness of the destination, translating into an offer of a differentiated tourist experience. Strategic planning requires an integrated vision of the territory, the environment and the development perspectives of the regions, allowing the structuring of a strong brand, because it is aggregated and authentic. Undoubtedly, this governance model requires leadership skills that promote empowerment and commitment for the production and dissemination of information by stakeholders. More than explaining exhaustively about the theoretical models of competitiveness, networks and governance, we sought to highlight the conditions and information that allow us to understand the issue of internationalization of destinations and explain the contribution of DMOs in this process. In conclusion, it can be said that the internationalization of tourism destinations is supported by the promotion of competitiveness, when this results from an organizational development 


\section{JOURNAL OF TOURISM AND SERVICES}

Issue 23, volume 12, ISSN 1804-5650 (Online)

www.jots.cz

strategy (intra-organizational level); the construction of a network system that promotes collaboration and the formalization of strategic alliances between organizations, supported by knowledge and innovation (inter-organizational level); and a governance model conducive with the development of territories and regions, when planning and decision-making are based on territorial identity (metaorganizational level). In this context, the role of the DMOs may involve: defining, implementing and monitoring the governance model that allows for the harmonization of the three levels of analysis set out; as well as guiding actors, structures and territories in a common project that reflects the regional identity and allows for the achievement of planned results. The multiplicity of variables that influence the 'internationalization of destinations' justifies carrying out studies that clarify this concept. The literature review highlights this aspect and motivates the work presented.

\section{Methods}

\subsection{Research criteria}

The objective of this study is to identify the factors that explain the internationalization process of destinations. Understanding the variables involved in this process, and their relationship can contribute to more effective management of the tourism system.

The search for papers was carried out in two phases. The first focused on the databases available in open access, which produced 237 documents and gave rise to the second phase of the study. This research was carried out in the period between 2014 and 2016, having consulted documents in physical support (libraries of Portuguese universities) and in digital support (Academic Google, DIALNET, EBSCO, ERIC, LATINDEX, ProQuest, Research Gate, REDIB, SCIELO, SCOPUS and Web of Science). These results have been the subject of previous publications (Mira \& Breda, 2019). In the second phase, the documentary sources were collected between September 2016 and February 2017, in the Scopus database and the Research Gate network. Publications in the scientific domains of Social Sciences, Business, Management and Accounting, Economics, Econometrics and Finance or Multidisciplinary were selected. Only documents whose article title, abstract and keywords mirrored the previously defined descriptors were considered. No other filters were applied, namely, year, author, type of document and sources. The survey focused on the following concepts: internationalization, tourism destinations, dimensions, factors, territories, identity, planning, innovation, cooperation, change, management, knowledge, business, resources, brand, communication, promotion, stakeholders and facilities. Seventysix publications were identified and analysed according to the following criteria: (i) written publications in previously defined languages; (ii) documents recorded in Portable Document Format (PDF) in text format; (iii) document available in full-text; d) full reading of the text. This process led to the exclusion of 40 documents, with 36 selected.

\subsection{Data analysis}

The documents were processed using VosViewer, for bibliometric analysis, and NVivo 10, for content analysis. Word frequency analyses, coding matrices and models of association between variables were performed. The word cloud and cluster analysis were extracted considering the 50 most frequent words, with three or more characters, applying Pearson's linear correlation coefficient (Pestana \& Gageiro, 2014). The coding matrices produced new configurations of relationships between variables, crossing categories and sources of information (Mozzato, Grzybovski \& Teixeira, 2016). The model extracted from the NVivo program illustrates the graphical representation of associations between categories. The results were grouped into 'structuring factors' and 'integrating factors'.

\subsection{Sample}


The documentary sample consists of 36 documents. It is essentially in the economy and geography of tourism that this topic has been investigated, with an emphasis on economic geography, with studies on the collaboration and integration of strategies in cross-border destinations (Table 6).

Table6. Scientific domain

\begin{tabular}{c|l}
\hline \hline SCIENTIFIC DOMAIN & \multicolumn{1}{|c}{ AUTHORS } \\
\hline Economy of tourism & $\begin{array}{l}\text { Bannò, Piscitello and Varum (2015); Bohlin, Brandt and Elbe. (2016); Booyens (2016); Booyens } \\
\text { and Rogerson (2015); De Noni, Orsi and Zanderighi(2014); Ferdinand and Williams (2013); Getz } \\
\text { and Page (2016); Nilsson, Eskilsson and Ek(2010); Sakharchuk, Kharitonova, Krivosheeva and } \\
\text { Ilkevich (2013); Sertakova, Koptseva (...) and Sergeeva, (2016); Vermeulen (2015); Vodeb and } \\
\text { Rudež (2016); Więckowski and Cerić (2016) }\end{array}$ \\
\hline Geography of tourism & $\begin{array}{l}\text { Badulescu, Hoffman, Badulescu and Simut(2016); Bernabé and Handrnández (2016); Blasco, } \\
\text { Guia and Prats(2014b); Booyens and Rogerson (2016); Brouder and Ioannides (2014); Clavé and } \\
\text { Wilson (2017); Escach and Vaudor (2014); Freestone (2007); Makkonen and Williams (2016); } \\
\text { Sarasa (2015); Szytniewski et al., (2017); Timothy et al., (2016); Weidenfeld (2013) }\end{array}$ \\
\hline Multidisciplinary & $\begin{array}{l}\text { Blasco, Guia and Prats (2014a); Farmaki (2015); Makkonen and Weidenfield (2016); Scuttari, } \\
\text { Volgger and Pechlaner(2016); Volgger and Pechlaner (2015); Yeoman and Beeton (2014) }\end{array}$ \\
\hline Economic geography & $\begin{array}{l}\text { Makkonen and Rohde (2016); Rovira (2016); Sanz-Ibáñez and Clavé (2016); Soares, Baidal and } \\
\text { Gândar, (2015) }\end{array}$ \\
\hline \hline
\end{tabular}

Source: own research

Between 2007 and 2013, some isolated publications appeared. From 2014, there has been greater interest in the internationalization of destinations among the scientific community. The trend line shown in Figure 1 predicts that research in this area will continue to grow (see Figure 1).

Figure 1. Time evolution of publications and trend line

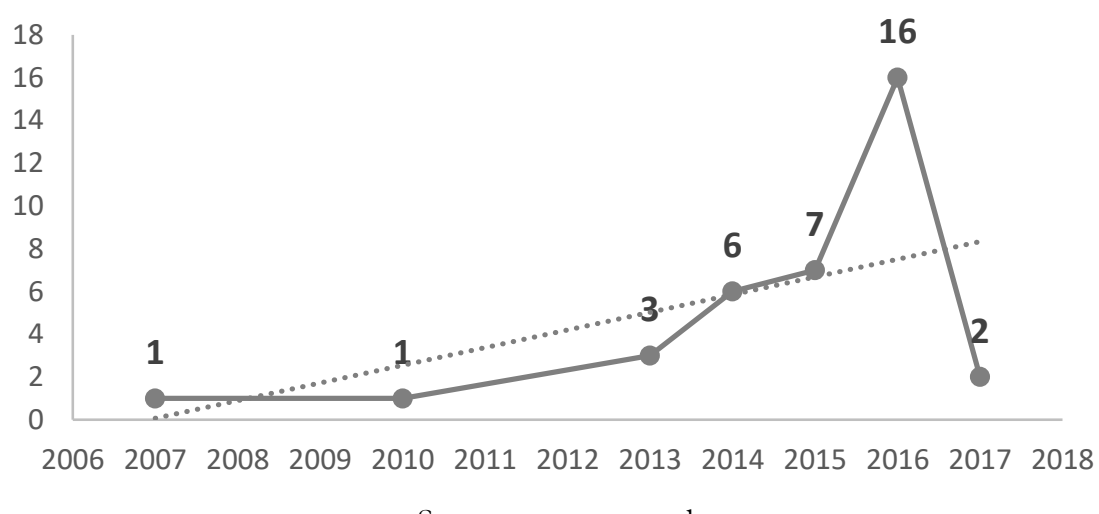

Source: own research

As for the geographical distribution of the countries of origin of the first authors, publications by European authors predominate ( 28 documents), followed by four publications by authors located in Africa, two on the American continent and two in Oceania (see Figure 2).

The 36 documents were published in 23 journals (see Table 7). Scientific journals in the field of geography and planning stand out, indicating that the internationalization of destinations is still very much associated with study of the territory.

Figure 2. Geographical distribution of publications 


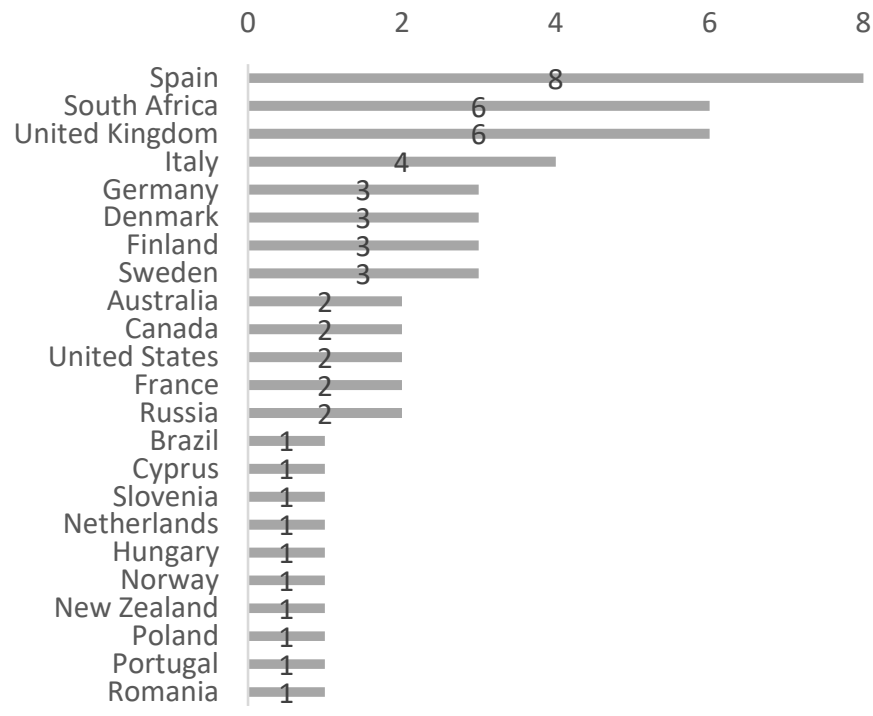

Source: own research

Table 7. Number of publications per Journal and their impact factor

\begin{tabular}{|c|c|c|}
\hline JOURNALS & FREQUENCY & IMPACT FACTOR \\
\hline Annals of Tourism Research & 3 & 5.908 \\
\hline European Planning Studies & 3 & 2.226 \\
\hline Regional Studies & 3 & 3.147 \\
\hline Tourism Geographies & 3 & 2.88 \\
\hline Anales de Geografia de la Universidad Complutense & 2 & 0.420 \\
\hline Journal of Sustainable Tourism & 2 & 3.400 \\
\hline Scandinavian Journal of Hospitality and Tourism & 2 & 2.508 \\
\hline Tourism Management & 2 & 7.432 \\
\hline Urban Forum & 2 & 1.386 \\
\hline Bulletin of Geography & 1 & 1.925 \\
\hline Cuadernos de Turismo & 1 & 0.174 \\
\hline CyberGeo & 1 & 0.300 \\
\hline International Journal of Knowledge-Based Development & 1 & 2.020 \\
\hline International Planning & 1 & 0.620 \\
\hline International Review of Management and Marketing & 1 & 0.170 \\
\hline Journal of Destination Marketing and Management & 1 & 4.279 \\
\hline Journal of Travel Research & 1 & 5.169 \\
\hline Lex Localis & 1 & 0.560 \\
\hline Local Economy & 1 & 1.360 \\
\hline Revija za Sociologiju & 1 & 0.300 \\
\hline Revista CIDOB d'Afers Internacionals & 1 & 0.180 \\
\hline Tourism Review & 1 & 1.460 \\
\hline World Applied Sciences Journal & 1 & --- \\
\hline
\end{tabular}

Source: own research

Table 8 indicates the publications most cited in later studies.

Table 8. Citations by publications 


\begin{tabular}{|c|c|c|}
\hline AUTHOR & TITLE & CITATIONS \\
\hline Weidenfeld (2013) & Tourism and cross border regional innovation systems & 19 \\
\hline Nilsson, Eskilsson and Ek (2010) & $\begin{array}{l}\text { Creating cross-border destinations: Interreg programmes and } \\
\text { regionalisation in the Baltic Sea area }\end{array}$ & 13 \\
\hline Getz and Page (2016) & Progress and prospects for event tourism research & 8 \\
\hline Ferdinand and Williams (2013) & International festivals as experience production systems & 7 \\
\hline Brouder and Ioannides (2014) & $\begin{array}{l}\text { Urban Tourism and Evolutionary Economic Geography: } \\
\text { Complexity and Co-evolution in Contested Spaces }\end{array}$ & 4 \\
\hline $\begin{array}{l}\text { De Noni, Orsi and Zanderighi } \\
\text { (2014) }\end{array}$ & Attributes of Milan influencing city brand attractiveness & 4 \\
\hline Freestone (2007) & The internationalization of the city beautiful & 4 \\
\hline Booyens (2016) & $\begin{array}{l}\text { Global-local trajectories for regional competitiveness: Tourism } \\
\text { innovation in the Western Cape }\end{array}$ & 3 \\
\hline $\begin{array}{l}\text { Sakharchuk, Kharitonova, } \\
\text { Krivosheeva and Ilkevich (2013) }\end{array}$ & $\begin{array}{l}\text { The study of the present state and prospects of cultural tourism in } \\
\text { the Russian Federation (Exemplifying Moscow Region) }\end{array}$ & 3 \\
\hline Blasco, Guiaand Prats (2014b) & $\begin{array}{l}\text { Tourism destination zoning in mountain regions: A consumer-based } \\
\text { approach }\end{array}$ & 2 \\
\hline Farmaki (2015) & Regional network governance and sustainable tourism & 2 \\
\hline $\begin{array}{l}\text { Scuttari, VolggerandPechlaner } \\
\text { (2016) }\end{array}$ & $\begin{array}{l}\text { Transition management towards sustainable mobility in Alpine } \\
\text { destinations: Realities and realpolitik in Italy's South Tyrol region }\end{array}$ & 2 \\
\hline Blasco, Guia and Prats (2014a) & Emergence of governance in cross-border destinations & 1 \\
\hline Booyens and Rogerson (2015) & Creative Tourism in Cape Town: An Innovation Perspective & 1 \\
\hline Escach and Vaudor (2014) & $\begin{array}{l}\text { Réseaux de villes et processus de recomposition des niveaux: Le cas } \\
\text { des villes baltiques }\end{array}$ & 1 \\
\hline Makkonen and Rohde (2016) & $\begin{array}{l}\text { Cross-border regional innovation systems: Conceptual } \\
\text { backgrounds, empirical evidence and policy implications }\end{array}$ & 1 \\
\hline Sarasa (2015) & $\begin{array}{l}\text { Myth and strategies for a romantic destination: The city of Teruel } \\
\text { (Spain) }\end{array}$ & 1 \\
\hline Volgger and Pechlaner (2015) & $\begin{array}{l}\text { Governing networks in tourism: What have we achieved, what is still } \\
\text { to be done and learned? }\end{array}$ & 1 \\
\hline Więckowski and Cerić (2016) & $\begin{array}{l}\text { Evolving tourism on the Baltic Sea coast: Perspectives on change in } \\
\text { the Polish maritime borderland }\end{array}$ & 1 \\
\hline Yeoman and Beeton (2014) & $\begin{array}{l}\text { The state of tourism futures research: An Asian Pacific ontological } \\
\text { perspective }\end{array}$ & 1 \\
\hline
\end{tabular}
Source: own research

Most of the knowledge generated in this field translates into exploratory studies (Table 9).

Table 9. Research objective

\begin{tabular}{|c|c|}
\hline $\begin{array}{l}\text { RESEARCH } \\
\text { OBJECTIVE }\end{array}$ & AUTHORS \\
\hline Exploratory studies & $\begin{array}{l}\text { Bernabé and Hernández (2016); Blasco et al. (2014a); Blasco et al. (2014b); Bohlin et al. (2016); } \\
\text { Booyens (2016); Boyens and Rogersosn (2015, 2016); Brouder and Ioannides (2014); Clavé and } \\
\text { Wilson (2017); Escach and Vaudor 82014); Farmaki (2015); Freestone (2007); Ferdinand and } \\
\text { Williams (2013); Getz and Page (2016); Makkonen and Rohde (2016); Makkonen and } \\
\text { Weidenfield (2016); Makkonen and Williams (2016); Nilsson et al. (2010); Rovira (2016): Sans- } \\
\text { Ibáñez and Clavé (2016); Sarasa (2015); Scuttari et al. (2016); Sertakova et al. (2016); Soares et } \\
\text { al. (2015); Szytniewski et al. (2017); Vermeulen (2015); Vodeb and Rudež (2016); Weidenfeld } \\
\text { (2013); Yeoman and Beeton (2014). }\end{array}$ \\
\hline Descriptive studies & $\begin{array}{l}\text { Badulescu et al. (2016); Bannó et al. (2015); De Noni et al. (2014); Sakharchuk et al. (2013); } \\
\text { Volgger and Pechlaner (2015); Wieckowski and Cerič (2016). }\end{array}$ \\
\hline
\end{tabular}




\section{JOURNAL OF TOURISM AND SERVICES}

Issue 23, volume 12, ISSN 1804-5650 (Online)

www.jots.cz

There are 26 empirical studies. Five publications are systematic literature reviews and the other five present a theoretical reflection on the internationalization of destinations. Empirical studies focus on inter-destination collaboration, both in border destinations and between cities. Case studies on the collaborative governance models of network destinations predominate (Table 10).

\section{Table 10. Kind of study}

\begin{tabular}{c|l}
\hline \hline KIND OF STUDY & \multicolumn{1}{c}{ AUTHORS } \\
\hline Empirical study & $\begin{array}{l}\text { Badulescu et al., (2016); Bannó et al., (2015); Bernabé and Hernandez (2016); Blasco et al., } \\
\text { (2014a); Blasco et al., (2014b); Bohlin et al., (2016); Booyens (2016); Booyens and Rogerson (2015, } \\
\text { 2016); Clavé and Wilson (2017); De Noni et al., (2014); Escach and Vaudor (2014); Farmaki } \\
\text { (2015);Ferdinand and Williams (2013); Freestone (2007); Makkonen and Weidenfield (2016); } \\
\text { Nilsson et al., (2010); Sakharchuk et al., (2013); Sanz-Ibáñez and Clavé (2016); Scuttari et al., } \\
\text { (2016); Sertakova et al., (2016); Szytniewski et al., (2017); Vermeulen (2015); Vodeb and Rudež } \\
(2016) ; \text { Volgger and Pechlaner (2015); Więckowski and Cerić (2016) }\end{array}$ \\
\hline $\begin{array}{l}\text { Systematic review } \\
\text { studies }\end{array}$ & $\begin{array}{l}\text { Brouder and Ioannides (2014); Getz and Page (2016); Makkonen and Rohde (2016); Makkonen } \\
\text { and Williams (2016); Soares et al., (2015) }\end{array}$ \\
\hline $\begin{array}{l}\text { Theoretical reflection } \\
\text { Rovira (2016); Sarasa (2015); Timothy, Saarien and Viken (2016); Weidenfeld (2013); Yeoman } \\
\text { and Beeton (2014) }\end{array}$ \\
\hline \hline
\end{tabular}

Source: own research

Table 11 gives indications for future research, highlighting the relationship between the internationalization of destinations and systems of innovation, policies, planning, governance and attributes of the territory. They also focus on the role of DMOs in the organization of these systems.

\section{Table 11. Research focus}

\begin{tabular}{|c|c|c|}
\hline RESEARCH FOCUS & PUBLICATIONS & FREQUENCY \\
\hline Planning & $\begin{array}{l}\text { Blasco et al., (2014b); Brouder and Ioannides (2014); Freestone (2007); } \\
\text { Makkonen and Williams (2016); Rovira (2016); Soares et al., (2015) }\end{array}$ & 6 \\
\hline Public policy & $\begin{array}{l}\text { Bannó et al., (2015); Bernabé and Hernandez (2016); Bohlin et al., (2016); } \\
\text { Nilsson et al., (2010); Szytniewski et al., (2017); Timothy et al., (2016) }\end{array}$ & 6 \\
\hline Products & $\begin{array}{l}\text { Ferdinand and Williams (2013); Getz and Page (2016); Sakharchuk et al., } \\
\text { (2013); Sarasa (2015); Vermeulen (2015) }\end{array}$ & 5 \\
\hline Innovation & $\begin{array}{l}\text { Booyens (2016); Booyens and Rogerson (2015, 2016); Makkonen and } \\
\text { Rohde (2016); Weidenfeld (2013) }\end{array}$ & 5 \\
\hline Governance & $\begin{array}{l}\text { Blasco et al., (2014a); Farmaki (2015); Scuttari et al., (2016); Volgger and } \\
\text { Pechlaner (2015); }\end{array}$ & 4 \\
\hline Development & $\begin{array}{l}\text { Clavé and Wilson (2017); Makkonen and Weidenfield (2016); } \\
\text { Więckowski and Cerić (2016) }\end{array}$ & 3 \\
\hline Cooperation & Badulescu et al., (2016); Vodeb and Rudež (2016) & 2 \\
\hline Marketing & De Noni et al., (2014); Sertakova et al., (2016); & 2 \\
\hline Networks & Escach and Vaudor (2014); Sanz-Ibáñez and Clavé (2016); & 2 \\
\hline Internationalization & Yeoman and Beeton (2014) & 1 \\
\hline
\end{tabular}

Source: own research

Clarifying the concept of 'Internationalization of destinations' implies continuing to investigate the management of destinations, the role of people in this process, governance, collaboration and networks (Figure 3). 


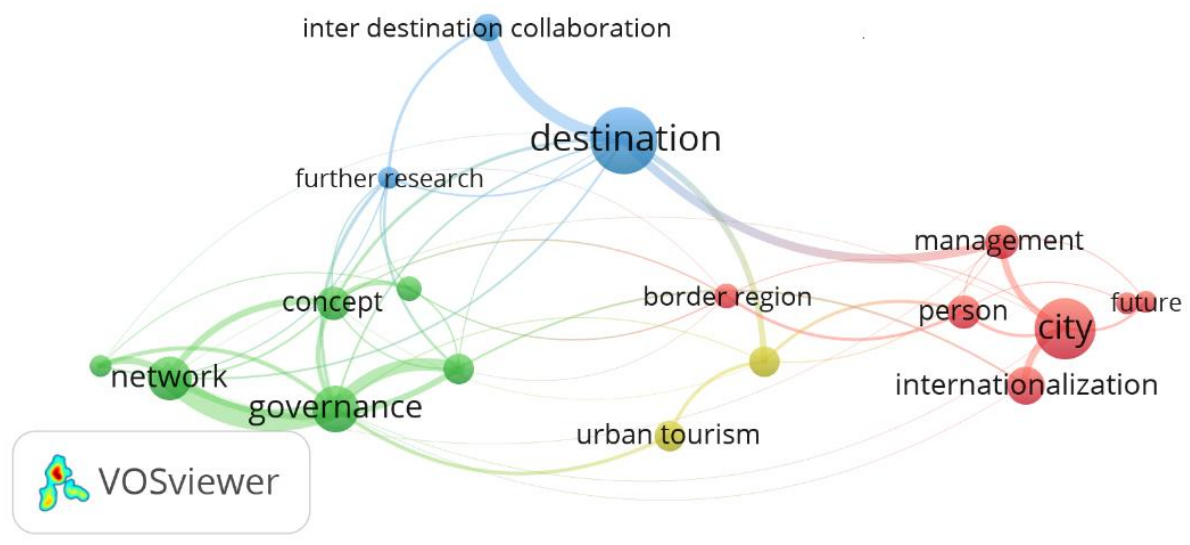

Source: own research

\section{Results}

\subsection{Structuring factors: Territory and product}

Figure 4 shows two distinct fields: at one pole, identity or culture, and at the opposite pole, economics and business. Cluster analysis shows the contrast between two logics that coexist here and facilitates their visualization: on the one hand, the economic dimension (companies, businesses, products, among others); on the other, the logic of the symbolic and cultural, the social and political, as well as the managerial. Economy and business are associated with companies' competitiveness, through knowledge and innovation in the creation of new products, as well as in the attractiveness of destinations, by increasing marketing strategies capable of promoting and creating a brand. Collaborative relationships must be supported by policy planning that fosters cooperation between public and private organizations and with other stakeholders.

The territory has institutions, processes, services and businesses that reflect the culture and identity of the region and highlight the integrated system of relations between stakeholders and policies. This dynamic has an effect on the attractive and competitive capacity of destinations, as long as it is integrated in the products. To this end, the strategy followed must be based on knowledge, innovation and marketing of the destination and products. The limits or boundaries of these same destinations must also be taken into account (see Figure 5).

Table 12 highlights the different concepts associated with what has been called 'structuring factors' for the internationalization of destinations. The results suggest that:

a) there is an association between structuring factors for the internationalization of destinations, product and governance;

b) from the planning perspective, the relationship between product, territory and governance emerges in the tourist destination project;

c) the relationship between policies, territory, product and governance indicates that product innovation must be supported by the identity of the territory and networks;

d) stimulating the economy, competitiveness and business depends on the relationship between product, territory and governance;

e) the governance model for the territory and tourism products must emerge from the coordination of the destination project, supported by a network of stakeholders that promotes innovation and competitiveness;

Figure 4. Cluster analysis by structuring factors 


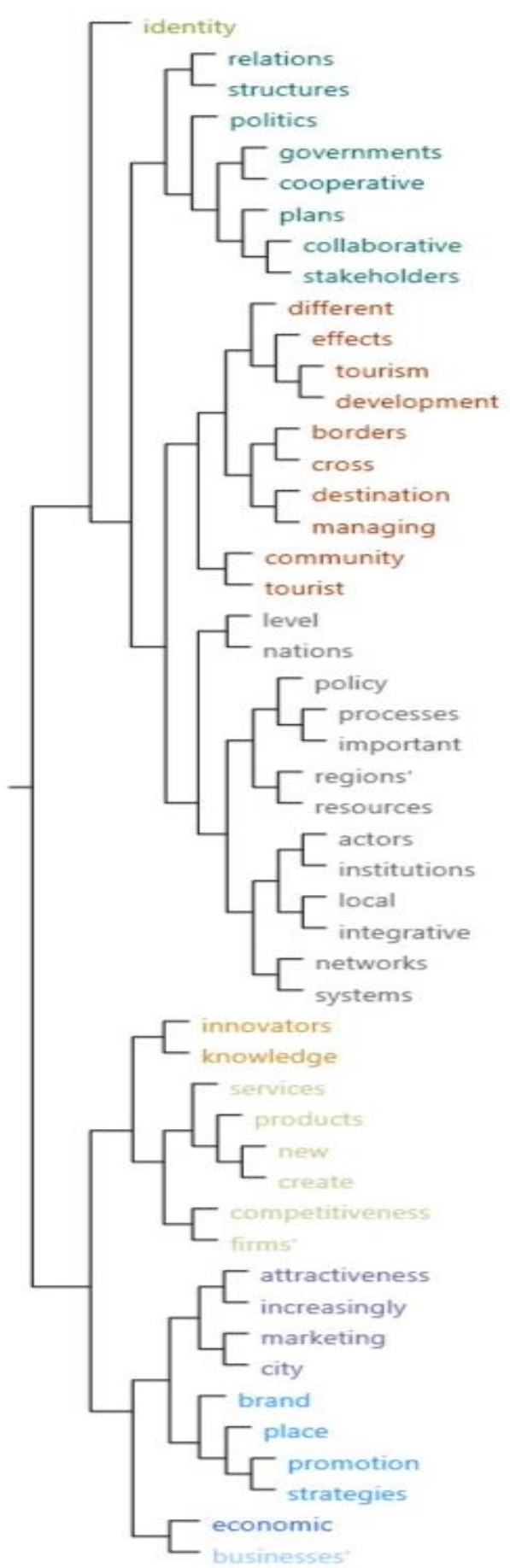

Source: own research

f) competitiveness depends on a marketing strategy that consolidates and promotes a brand; the destination brand must emerge from the collaborative strategies resulting from the network of stakeholders;

g) the network governance model facilitates product innovation.

The competitiveness of destinations and products can be seen in the access to business opportunities and the penetration of new markets; these depend on the existence of networks that promote innovation; the governance model is what guarantees the authenticity of the destination project. 
Figure 5. Structural factors by word cloud

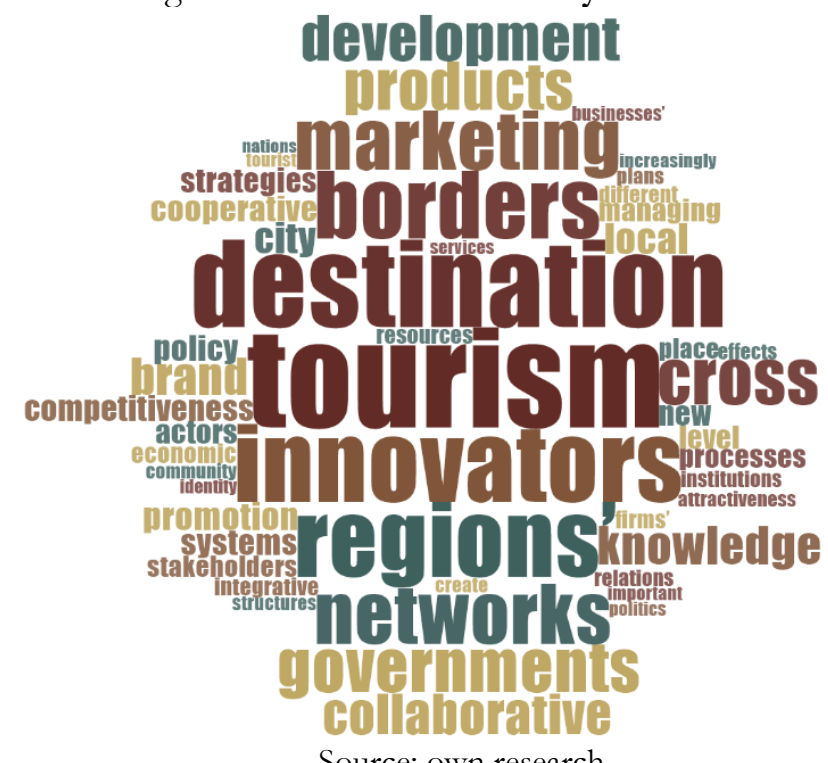

Table 12. 'Structuring factors' by research focus

\begin{tabular}{|c|c|c|c|c|c|c|c|c|c|c|}
\hline & 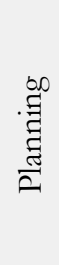 & $\begin{array}{l}\frac{\mathscr{U}}{\tilde{U}} \\
\frac{0}{0} \\
2\end{array}$ & 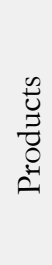 & 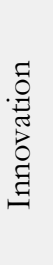 & $\begin{array}{l}\text { Uू } \\
\text { ज्ञ } \\
\text { ज्ञ } \\
0 \\
0\end{array}$ & 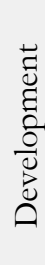 & 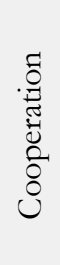 & 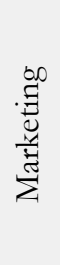 & 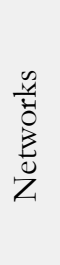 & 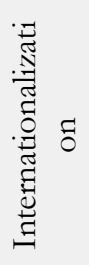 \\
\hline 1:Structuring factors & 6 & 6 & 5 & 5 & 4 & 3 & 2 & 2 & 2 & 1 \\
\hline 2. Product & 6 & 6 & 5 & 5 & 4 & 3 & 2 & 2 & 2 & 1 \\
\hline 3. Competitiveness & 5 & 5 & 5 & 5 & 4 & 3 & 2 & 2 & 1 & 1 \\
\hline 4. Marketing & 3 & 4 & 3 & 3 & 3 & 2 & 2 & 2 & 1 & 0 \\
\hline 5. Strategy & 3 & 3 & 2 & 3 & 3 & 2 & 2 & 2 & 1 & 0 \\
\hline 6. Brand & 2 & 2 & 2 & 2 & 2 & 1 & 1 & 2 & 0 & 0 \\
\hline 7. Promotion & 3 & 4 & 1 & 2 & 2 & 1 & 2 & 2 & 1 & 0 \\
\hline 8. Opportunities & 5 & 5 & 4 & 5 & 3 & 3 & 2 & 1 & 1 & 1 \\
\hline 9. Financing & 2 & 5 & 2 & 2 & 2 & 2 & 2 & 0 & 1 & 0 \\
\hline 10. Markets & 4 & 5 & 3 & 4 & 2 & 3 & 1 & 1 & 1 & 1 \\
\hline 11. Business & 4 & 5 & 4 & 5 & 3 & 3 & 2 & 1 & 1 & 1 \\
\hline 12. Quality & 1 & 1 & 3 & 1 & 1 & 0 & 1 & 1 & 0 & 0 \\
\hline 13. Economic dimension & 5 & 5 & 5 & 5 & 1 & 3 & 1 & 1 & 1 & 0 \\
\hline 14. Strategic dimension & 2 & 2 & 0 & 1 & 1 & 1 & 1 & 0 & 1 & 0 \\
\hline 15. Inter-organizational level & 3 & 6 & 2 & 4 & 4 & 3 & 2 & 0 & 2 & 0 \\
\hline 16. Intra-organizational level & 4 & 6 & 2 & 3 & 4 & 3 & 2 & 0 & 2 & 0 \\
\hline 17. Networks & 5 & 6 & 4 & 5 & 4 & 3 & 2 & 2 & 2 & 1 \\
\hline 18. Innovation & 4 & 6 & 4 & 5 & 4 & 3 & 1 & 1 & 2 & 1 \\
\hline 19. Partnerships & 2 & 3 & 3 & 5 & 3 & 3 & 1 & 0 & 2 & 1 \\
\hline 20. Products & 3 & 6 & 3 & 5 & 2 & 3 & 1 & 1 & 1 & 1 \\
\hline 21. Marketing & 4 & 2 & 2 & 3 & 2 & 1 & 2 & 2 & 0 & 0 \\
\hline 22. Destination brand & 3 & 2 & 2 & 2 & 2 & 1 & 1 & 2 & 0 & 0 \\
\hline
\end{tabular}




\begin{tabular}{|l|l|l|l|l|l|l|l|l|l|l|} 
23. Collaborative marketing & 2 & 2 & 1 & 3 & 2 & 1 & 2 & 2 & 0 & 0 \\
\hline 24. Territory & 6 & 6 & 5 & 5 & 4 & 3 & 2 & 2 & 2 & 1 \\
\hline 25. Territorial dimension & 1 & 2 & 0 & 1 & 0 & 1 & 1 & 0 & 0 & 0 \\
\hline 26. Governance & 6 & 6 & 5 & 5 & 4 & 3 & 2 & 2 & 2 & 1 \\
\hline 27. Coordination & 6 & 5 & 4 & 5 & 4 & 3 & 2 & 2 & 2 & 1 \\
\hline 28. Destination project & 6 & 5 & 4 & 5 & 4 & 3 & 2 & 2 & 2 & 1 \\
\hline 29. Stakeholders network & 5 & 3 & 4 & 5 & 4 & 3 & 2 & 1 & 2 & 1 \\
\hline 30. Identity & 3 & 6 & 3 & 4 & 3 & 2 & 2 & 2 & 2 & 1 \\
\hline 31. Destination brand & 2 & 2 & 3 & 1 & 2 & 1 & 2 & 2 & 1 & 0 \\
\hline 32. Products and services & 2 & 5 & 2 & 3 & 2 & 1 & 1 & 2 & 1 & 1 \\
\hline 33. Meta-organizational level & 3 & 5 & 2 & 4 & 4 & 3 & 2 & 0 & 2 & 0 \\
\hline
\end{tabular}

\subsection{Integrating factors: Governance and DMOs}

Figure 7 organizes the information into three distinct branches. At the top, the economic dimension is associated with innovation, competitiveness, business and the need for companies to increase investment in marketing and promotion, without losing sight of the target audience. The central branch highlights the issue of attractiveness depending on collaborative strategies between stakeholders and knowledge networks. The bottom branch of the figure explains the dynamic relationships between policies, planning, development and change management. What integrates these diverse factors are the collaborative strategies between stakeholders, which include the community and tourists, knowledge and innovation.

Figure 6 illustrates the themes associated with the 'integrating factors' category, namely: tourism, destinations, regions, knowledge, innovation, networks, marketing, collaboration, limits, governance and development. At one pole is governance of the spatial structure of destinations, and at the opposite pole, innovation, networks and collaborative marketing. In the lower field of the image we have the development policies of the territory, and in the upper field, we have the strategy for this to happen.

Figure 6. Integrating factors by word cloud

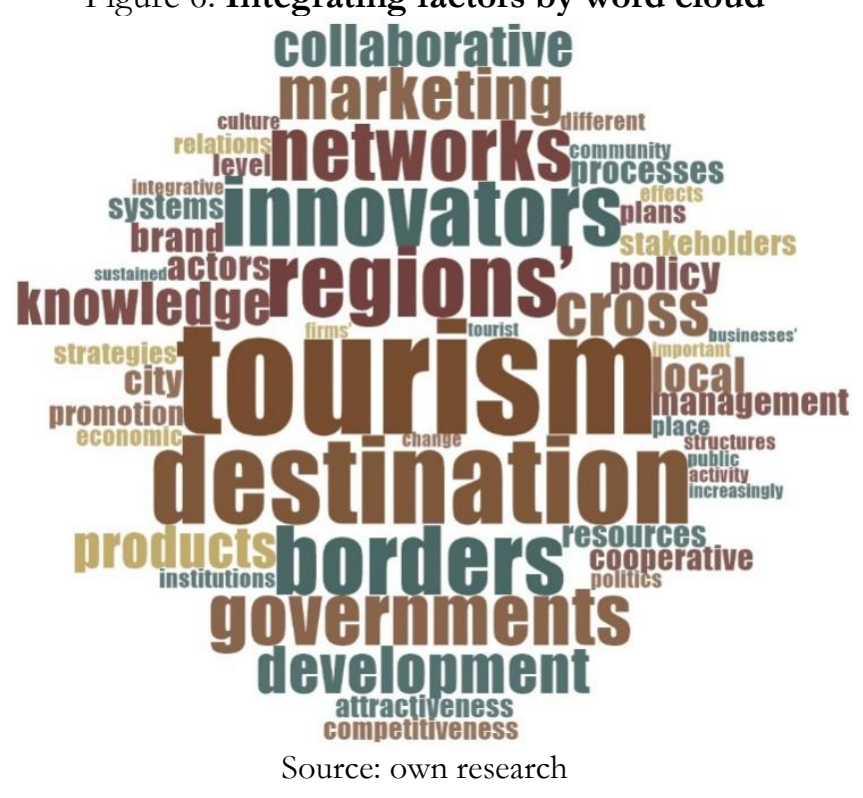

Figure 6. Cluster analysis by integrating factors 


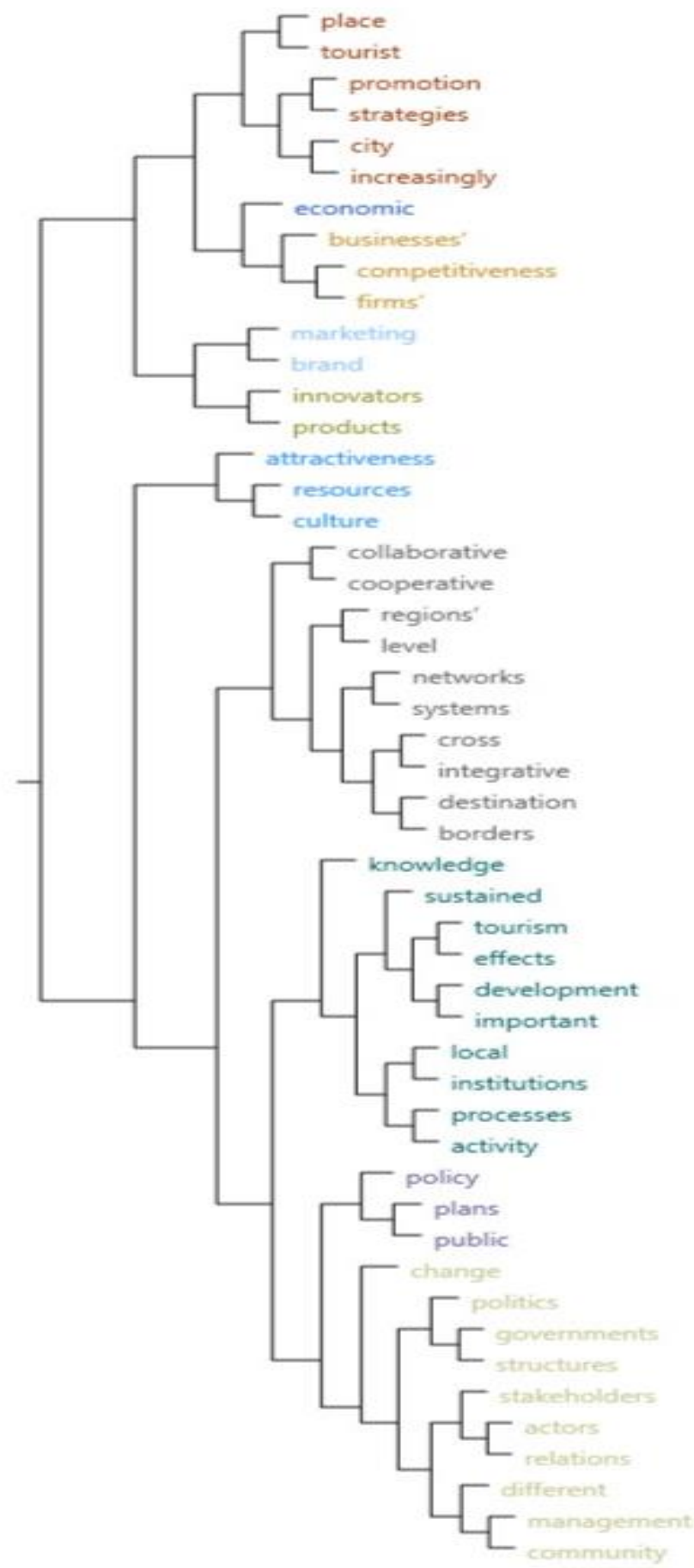

Source: own research

Table 13 reveals the importance of the integrating role of the DMO, reflected in the policy governance model and in planning. DMOs must integrate the elements of the system, managing the associations between:

a) planning, networks, stakeholders, cultural and heritage resources, human and political resources;

b) innovation, collaborative strategies and knowledge;

c) human resources, cooperation, negotiation and change process;

d) marketing, human resources and knowledge; 


\section{JOURNAL OF TOURISM AND SERVICES}

Issue 23, volume 12, ISSN 1804-5650 (Online)

www.jots.cz

e) knowledge, policies, human resources, and stakeholder collaboration and management of the change process.

Table 13. 'Integrating factors' by research focus

\begin{tabular}{|c|c|c|c|c|c|c|c|c|c|c|}
\hline & $\begin{array}{l}\underset{\infty}{G} \\
\underset{\Xi}{\Xi} \\
\stackrel{\Xi}{\Xi}\end{array}$ & \begin{tabular}{l}
$\mathscr{U}$ \\
$\frac{\mathscr{U}}{0}$ \\
\hdashline 0 \\
$\mathcal{O}$
\end{tabular} & 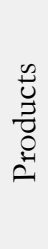 & 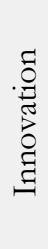 & 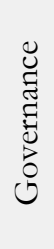 & 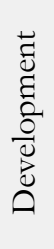 & 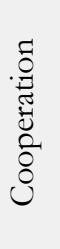 & 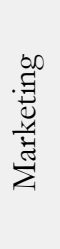 & 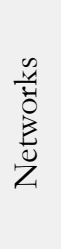 & 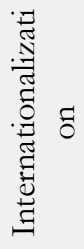 \\
\hline 1. Knowledge & 3 & 5 & 3 & 5 & 3 & 2 & 1 & 2 & 2 & 1 \\
\hline 2. Create & 2 & 2 & 1 & 5 & 2 & 2 & 1 & 1 & 0 & 1 \\
\hline 3. Share & 1 & 2 & 2 & 4 & 2 & 2 & 1 & 1 & 0 & 1 \\
\hline 4. Integrating factors & 6 & 6 & 5 & 5 & 4 & 3 & 2 & 2 & 2 & 1 \\
\hline 5. DMOs & 6 & 6 & 5 & 5 & 4 & 3 & 2 & 2 & 2 & 1 \\
\hline 6. Planning & 6 & 6 & 3 & 5 & 4 & 3 & 2 & 2 & 2 & 1 \\
\hline 7. Policies & 6 & 6 & 3 & 4 & 4 & 3 & 2 & 2 & 2 & 1 \\
\hline 8. Resources & 5 & 4 & 5 & 4 & 4 & 3 & 2 & 2 & 2 & 1 \\
\hline 9. Cultural and heritage & 5 & 3 & 5 & 3 & 3 & 2 & 2 & 1 & 1 & 0 \\
\hline 10. Humans resources & 3 & 4 & 4 & 3 & 3 & 2 & 2 & 2 & 2 & 1 \\
\hline 11. Natural resources & 3 & 2 & 2 & 2 & 2 & 1 & 2 & 1 & 1 & 0 \\
\hline 12. Support resources & 3 & 3 & 2 & 3 & 3 & 2 & 2 & 1 & 1 & 0 \\
\hline 13. Tourism resources & 3 & 3 & 3 & 3 & 2 & 1 & 2 & 1 & 0 & 0 \\
\hline 14. Stakeholders & 4 & 5 & 5 & 5 & 4 & 3 & 2 & 2 & 2 & 1 \\
\hline 15. Change & 2 & 3 & 3 & 2 & 3 & 2 & 2 & 2 & 1 & 1 \\
\hline 16. Negotiation & 2 & 3 & 2 & 4 & 4 & 1 & 1 & 1 & 1 & 1 \\
\hline 17. Participation & 1 & 3 & 2 & 4 & 4 & 1 & 2 & 1 & 1 & 1 \\
\hline 18. Collaborative strategy & 3 & 3 & 2 & 5 & 4 & 3 & 2 & 1 & 1 & 1 \\
\hline 19. Integrating function & 1 & 3 & 1 & 1 & 3 & 1 & 1 & 0 & 0 & 1 \\
\hline
\end{tabular}

\section{Discussion}

Data analysis allowed us to identify the dimensions and mediating variables that explain the internationalization process of destinations. It was found that the structuring factors of tourism destinations are the 'Territory' and the 'Products'. Destinations are built through social, cultural, political and economic relationships, so they must be organized based on their attractiveness potential. The existence of diverse attractions, with good connections to the main markets, contributes to this attractiveness (Blasco et al., 2014b; Brouder \& Ioannides, 2014). Competitiveness between destinations implies local policies that encourage new ways of acting, undertaking, innovating, leading and organizing the labor market. Under these conditions, destinations emerge as successful strategic units that effectively contribute to the economic development of the regions (Badulescu, et al., 2016; Blasco et al., 2014a; Bholin et al., 2016; Volgger \& Pechlaner, 2015). The issue of internationalization of destinations, from the point of view of territory, highlights the ability of regions to attract "talents" and their institutional articulation (Badulescu et al., 2016; De Noni et al., 2014; Makkonen \& Williams, 2016). The integration of ecological, cultural, social, economic and political subsystems results in governance structures that give rise to local networks that explore and protect the unique signature of destinations (Sertakova et al., 2016; Soares et al., 2015; Scuttar et al., 2016). These structures, more attentive to the management of symbolic and intangible resources of territories, because they are at their core and are imbued with the local culture, 


\section{JOURNAL OF TOURISM AND SERVICES}

Issue 23, volume 12, ISSN 1804-5650 (Online)

www.jots.cz

are also more effective in managing this process (Szytniewski et al., 2017). Another equally important aspect is the articulation of regional identities with the destination's marketing strategy. The profile of tourists has been changing, and it is verified that they feel captivated by endogenous attractions that portray the uniqueness of the regions (Badulescu, et al., 2016; Nilsson et al., 2010; Sarasa, 2015). In the internationalization of destinations, the competitiveness of products depends on innovation, quality and their ability to reflect this identity. Under these conditions, the territories tend to be attractive, both for tourists and for highly qualified workers. These two factors attract investment, triggering a dynamic between demand, fixing "talents" and investing in different businesses. Over time, this movement triggers a spiral of self-stimulating initiatives (Booyens \& Rogerson, 2015, 2016; Clavé \& Wilson, 2017; Vermeulen, 2016). The new context requires that tourism products evolve towards the tourist experience, created from the activation of cultural and natural resources of a given region (Bernabé \& Hernández, 2016). Emphasis is placed on a product management process that places tourists at the center of product design, and the markets at the final stage of this chain (Blasco et al., 2014b; Bohlin et al., 2016). The offer of the tourist experience is based on a form of creative tourism that places innovation at the center of product development, responding to changing demand motivations. This model requires increased collaboration between different stakeholders from different sectors of activity, leading to a shared strategy for defining products (Booyens \& Rogerson, 2015). Creative tourism encourages product variety and differentiation, reinventing and assigning value to them (Bohlin et al., 2016; Sanz-Ibáñez \& Clavé, 2016). However, the exoticism, sophistication and renewal of the offer, in the sense of innovation supported by the uniqueness of the regions, implies that there is, on the part of local actors, a change in attitudes and procedures, necessary for the network definition of the destination strategy (Rovira , 2016; Sarasa, 2015; Soares et al., 2015; Szytniewski et al., 2017).

\section{Figure 8. Structuring factors model}

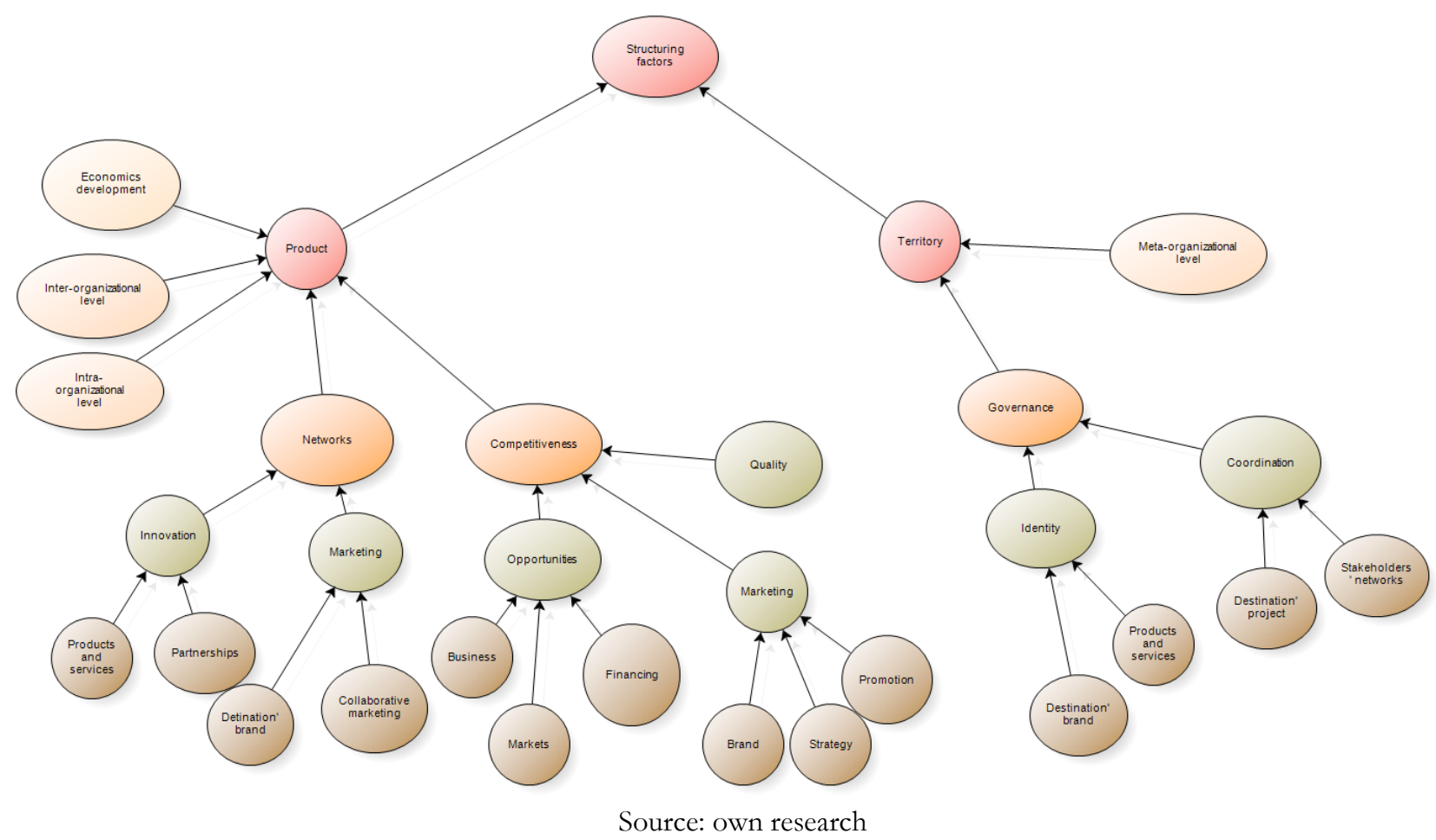




\section{JOURNAL OF TOURISM AND SERVICES}

Issue 23, volume 12, ISSN 1804-5650 (Online)

www.jots.cz

The organization of information in schematic models makes it easier to read. Figure 8 represents the category association model and restricts what is decisive in the 'structuring factors' of internationalization of destinations, namely: 'product' and 'territory'. It is observed the following:

a) tourism products contribute to a region's economic development when they are innovative and competitive; to be competitive it is necessary to have quality, as well as to know how to manage business expansion opportunities and have a marketing strategy that promotes the brand; it is the networks that consolidate the destination brand;

b) governance of the territory guarantees the conduct of the destination project, provided that it is supported by a network of stakeholders.

Another dimension of the internationalization of tourism destinations is the role of DMOs in managing this complex system. Network cooperation is based on a commitment to quality, innovation and learning. These are prerequisites for any successful collaborative action (Volgger \& Pechlaner, 2015). When destinations manage to organize themselves according to the principles of collaborative work, they increase their capacity to internationalize in a sustained way (Weidenfeld 2013). This collaboration leads to processes of behavioural, organizational and political change. For these reasons, the internationalization of tourism destinations requires that these factors be integrated into their strategic planning (Weickowski \& Cerić, 2016).

Collaborative innovation must be balanced at different levels. At the regional, national or international level, the actors differ, both in characteristics and in interests, so the destination project must include domains beyond tourism, such as: education, health, communications, civil protection and security, accessibility, including transport, commercial spaces, urban recovery or nature protection plans, among other aspects (Sanz-Ibáñez \& Clavé, 2016; Vodeb \& Rudež, 2016). The network governance of destinations, led by a DMO, should privilege a new vision and strategic orientation of local policies that allow achieving the results corresponding to the interests of the stakeholders, in a long-term perspective (Badulescu et al., 2016). One of the functions of these DMOs is resource planning. The challenge posed by stakeholder management has led public entities to create programs aimed at attracting foreign investment, aid for the promotion and marketing of products and the integration of R\&D activities in companies (Badulescu et al., 2016). Public entities have invested in the internationalization of destinations, mainly in attracting financial incentives, support in the promotion of products and in the formalization of some inter-destination networks (Blasco et al., 2014b). However, the role of DMOs has to go further, namely (Volgger \& Pechlaner, 2015):

a) destination planning must follow a strategy aimed at product harmonization and innovation, support for their commercialization and formalization of local associations of specific products (Bernabé \& Hernández, 2016);

b) financing policies should be allocated, preferably, to projects that result from entrepreneurship, as long as they demonstrate capacity for innovation and rely on endogenous resources (Bholin et al., 2016); 2016);

c) regional innovation must integrate teaching and research entities in this process (Booyens,

d) the public sector should be an element that facilitates the constitution of regional innovation systems, proposing policies that bring society closer to the knowledge economy (Booyens \& Rogerson, 2016; Brouder \& Ioannides, 2014);

e) DMOs should seek to implement regional innovation systems, integrated into international networks, without losing sight of the endogenous characteristics of local contexts (Makkonen \& Rhode, 2016);

f) the development of destinations requires DMOs that are responsible for planning the tourism system, for the integration of stakeholders in this project and for the definition of the destination's marketing and marketing strategy (Blasco et al., 2014b). 
Figure 9. Integrating factors model

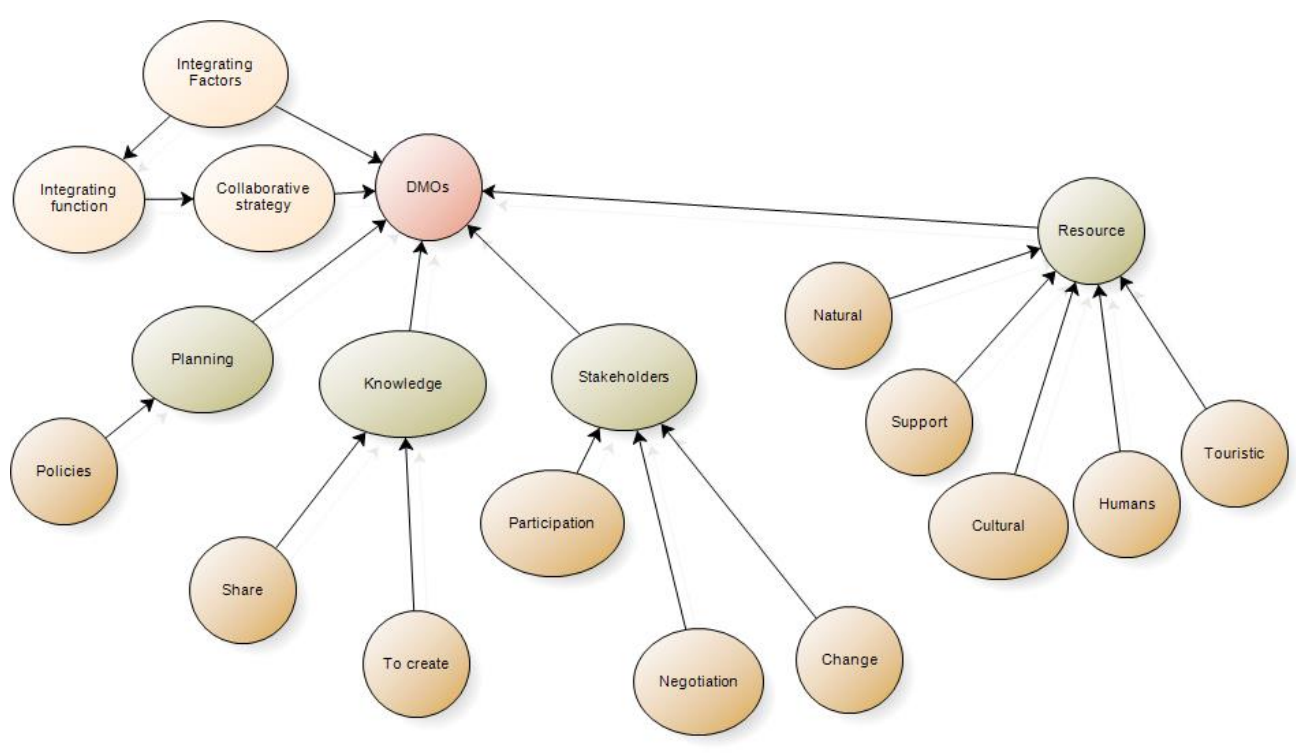

Source: own research

Figure 10. Tourism destinations' internationalization model (TDIM)

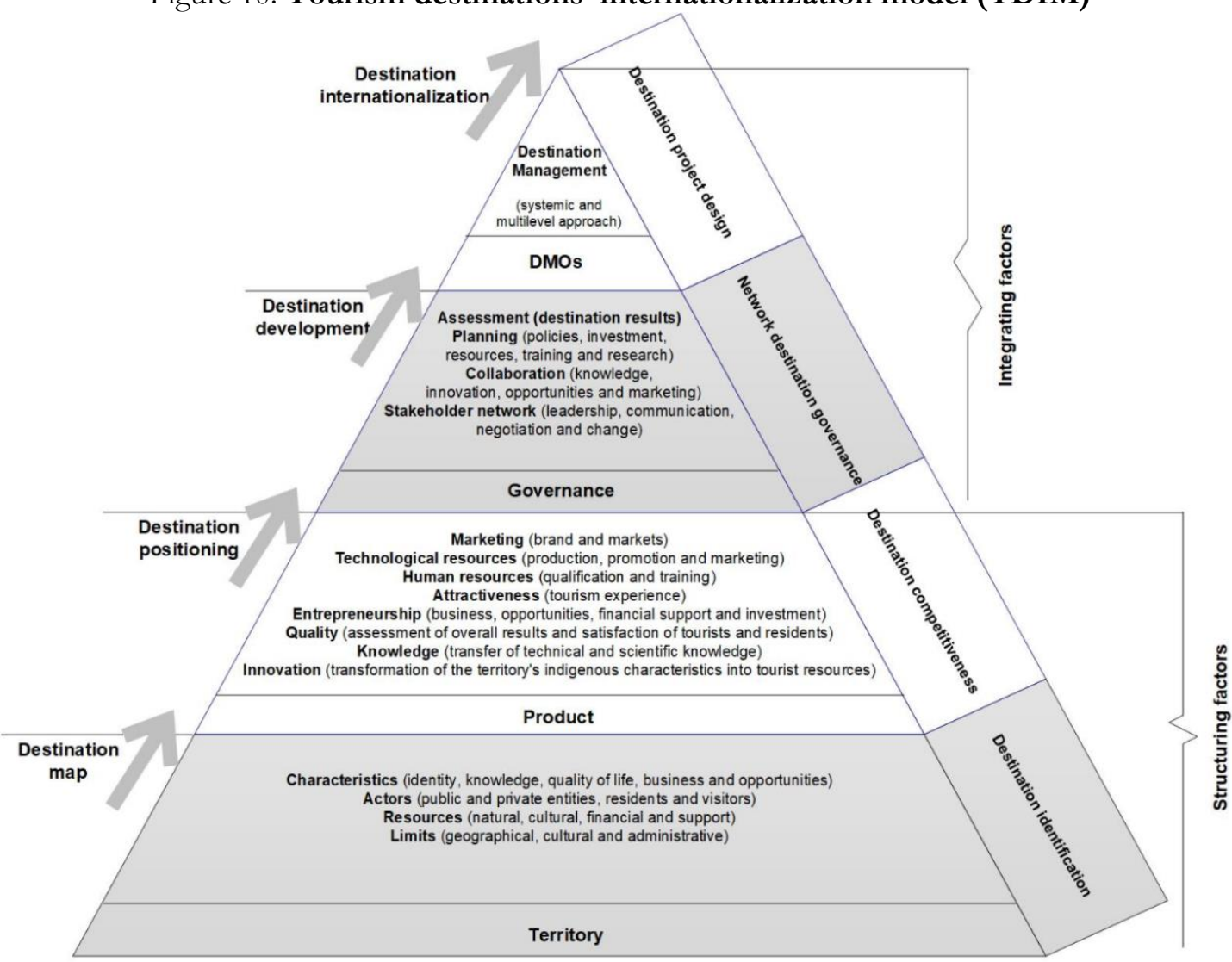

Source: own research 


\section{JOURNAL OF TOURISM AND SERVICES}

Issue 23, volume 12, ISSN 1804-5650 (Online)

www.jots.cz

Figure 9 shows that DMOs are assigned a role of integrating systems within systems. They are also considered responsible for planning policies and natural and cultural resources, human resources and knowledge management. DMOs must also boost the collaborative action of stakeholders, leading the process of change necessary to this new way of organizing destinations.

Finally, the model of internationalization of destinations, shown in Figure 10, clarifies the reading of the data previously presented. Mapping the destination, positioning it in the markets and drawing up a development plan towards internationalization, appear as the guidelines to be taken into account in the formulation of policies and in designing the strategy for tourist destinations. The multilevel approach (local, regional and national), together with the multidimensional perspective of tourism (economic, territorial and strategic), must be taken into account in the governance model. Competitiveness is associated with the innovation of products and services, which is essential to facilitate access to financing, business and market opportunities. It is also associated with a marketing strategy that consolidates the destination brand. To this end, this brand must emerge from the networking of the various stakeholders that contribute to the development of this joint project. It must reflect the identity of the territory. The coordinated action of stakeholders in product innovation operates through networks, at different levels, with the possibility of changing the composition of stakeholders, the nature of the actions in which they participate and the strategies outlined according to the level of analysis in which we find ourselves.

\section{Conclusion}

In summary, the issue of the internationalization of destinations is aligned with a concept of economic development in the territory that values quality, innovation, identity and differentiation. Being competitive, in this context, involves being innovative and being able to place on international markets what is distinctive because the products offered are imbued with cultural identity. Regions no longer compete only with their neighbours at the national level. Destinations compete with others that are often located far from their borders. The market is global. Therefore, local competitiveness has the challenge of selling products in this international market, taking them to the consumer's door. Hence the importance of marketing; it is not enough to produce; it is not enough to be different and have quality; it is essential to make these products attractive and easily accessible to customers around the world. However, management of these local / global dynamics becomes more effective when supported by a networked governance model. It is people who are enterprising, who think and define strategies, who communicate and who create. The dynamics of local governance networks transfer to stakeholders the power and legitimacy to undertake according to established policies and rules. An association has been established between internationalization of destinations, innovation and knowledge networks, so to become internationalized, destinations must be formed as regional / local innovation systems.

This perspective highlights the most pressing aspects of crisis management. The pandemic we are experiencing has reinforced the role of the image built by tourists in their motivation to travel. Planning, innovating, creating knowledge, working in a network and managing a brand that conveys confidence are, more and more, the priority in tourism. It is up to the DMOs to have a global view of the system and articulate its various components, directing the sector towards this new reality.

Until now, this theme has been mainly studied from the demand perspective, creating a gap in the existing knowledge about the associated organizational and systemic issues. The results of this investigation provide important guidelines, strategies and recommendations to both private and public decision-makers. It is suggested that an empirical study be carried out to validate the proposed conceptual model. Finally, explaining the internationalization of destinations is not a finished process. The research produced in a decade (2007-2017) was analyzed. It is essential to continue similar studies, justified by the profound changes observed in tourism resulting from the current pandemic. Conducting investigations 


\section{JOURNAL OF TOURISM AND SERVICES}

Issue 23, volume 12, ISSN 1804-5650 (Online)

www.jots.cz

that can compare the pre- and post-pandemic period in tourism internationalization movements are challenges for future investigations.

\section{References}

1. Aires, L. (2011). Paradigma qualitativo e práticas de investigação educacional. Lisboa: Universidade Aberta.

2. Badulescu, D., Hoffman, I., Badulescu, A, \& Simut, R. (2016). Local authorities' involvement in fostering Hungarian-Romanian cross-border cooperation in tourism. Lex Localis, Journal of Local Self-Government, 14(3), 337-358. https://doi.org/10.4335/14.3.337-358(2016)

3. Bannò, M., Piscitello, L., \& Varum, C. (2015). Determinants of the internationalization of regions: The role and effectiveness of public policy measures. Regional Studies, 49(7), 1208-1222. https://doi.org/10.1080/00343404.2013.821570

4. Belhassen, Y., \& Caton, K. (2009). Advancing understandings: A linguistic approach to tourism epistemology. Annals of Tourism Research, 36(2), 335-352. https://doi.org/10.1016/j.annals.2009.01.006

5. Benckendorff, P., \& Zehrer, A. (2013). A network analysis of tourism research. Annals of Tourism Research, 43, 121-149. https://doi.org/10.1016/j.annals.2013.04.005

6. Bernabé, C., \& Hernández, M. (2016). Turismo en Albarracín y Comarca: Acción pública local y dinâmica reciente en clave de desarrollo turístico sostenible. Anales de Geografía de la Universidad Complutense, 36(1), 173-194. doi:10.5209/rev AGUC.2016.v36.n1.52718

7. Blasco, D., Guia, J., \& Prats, L. (2014a). Emergence of governance in cross-border destinations. Annals of Tourism Research, 49, 159-173. doi:10.1016/j.annals.2014.09.002

8. Blasco, D., Guia, J., \& Prats, L. (2014b). Tourism destination zoning in mountain regions: A $\begin{array}{llll}\text { consumer-based } \quad \text { approach. Tourism } \quad \text { Geographies, } & \text { 16(3), }\end{array}$ https://doi.org/10.1080/14616688.2013.851267

9. Bohlin, M., Brandt, D., \& Elbe, J. (2016). Tourism as a vehicle for regional development in peripheral areas: Myth or reality? A longitudinal case study of Swedish regions. European Planning Studies, 24(10), 1788-1805. https://doi.org/10.1080/09654313.2016.1194807

10. Booyens, I. (2016). Global-local trajectories for regional competitiveness: Tourism innovation in the Western Cape. Local Economy, 31(1-2), 142-157. https://doi.org/10.1177/0269094215618598

11. Booyens, I., \& Rogerson, C. M. (2015). Creative tourism in Cape Town: An innovation perspective. Urban Forum, 26, 405-424. https://doi.org/10.1007/s12132-015-9251-y

12. Booyens, I., \& Rogerson, C. M. (2016). Unpacking the geography of tourism innovation in Western Cape Province, South Africa. Bulletin of Geography, Socio-economic Series, 31, 19-36. https://doi.org/10.1515/bog-2016-0002

13. Brouder, P., \& Ioannides, D. (2014). Urban tourism and evolutionary economic geography: Complexity and co-evolution in contested spaces. Urban Forum, 25, 419-430. https://doi.org/10.1007/s12132-014-9239-z

14. Cave, J., \& Dredge, D. (2020). Regenerative tourism needs diverse economic practices. Tourism Geographies, 22(3), 503-513. https://doi.org/10.1080/14616688.2020.1768434

15. Clavé, S., \& Wilson, J. (2017). The evolution of coastal tourism destinations: A path plasticity perspective on tourism urbanisation. Journal of Sustainable Tourism, 25(1), 96-112. https://doi.org/10.1080/09669582.2016.1177063

16. Coutinho, C. P. (2015). Avaliação da qualidade da investigação qualitativa: Algumas considerações teóricas e recomendações práticas. In F. Souza, D. Souza \& A. Costa (Orgs.), Investigação 


\section{JOURNAL OF TOURISM AND SERVICES}

Issue 23, volume 12, ISSN 1804-5650 (Online)

www.jots.cz

qualitativa: Inovação, dilemas e desafios (vol. 2, pp. 101-121). Oliveira de Azeméis, Portugal: Ludomedia.

17. Creswell, J. (2007). Projeto de pesquisa. Métodos qualitativo, quantitativo e misto (2a ed.). Porto Alegre: Artmed Editora.

18. De Noni, I., Orsi, L., \& Zanderighi, L. (2014). Attributes of Milan influencing city brand attractiveness. Journal of Destination Marketing \& Management, 3, 218-226. https://doi.org/10.1016/i.jdmm.2014.06.001

19. Entina, T., Karabulatova, I.,Kormishova, A., Ekaterinovskaya, M., \&o Troyanskaya, M. (2021). Tourism industry management in the global transformation: Meeting the needs of generation z. Polish Journal of Management Studis, 23(2), 130-148. https://doi.org/10.17512/pjms.2021.23.2.08

20. Escach, N., \& Vaudor, S. (2014). Réseaux de villes et processus de recomposition des niveaux: Le cas des villes baltiques. Cybergeo: European Journal of Geography, 679, 1-24. https://doi.org/10.4000/cybergeo.26336

21. Farmaki, A. (2015). Regional network governance and sustainable tourism. Tourism Geographies,17(3), 385-407. https://doi.org/10.1080/14616688.2015.1036915

22. Ferdinand, N., \& Williams, N. (2013). International festivals as experience production systems. Tourism Management, 34, 202-210. https://doi.org/10.1016/j.tourman.2012.05.001

23. Fernando, I. N. (2020). Tourism competitiveness by shift-share analysis to way-forward destination management: A case study for Sri Lanka. Journal of Tourism and Services, 21(11), 88-102. https://doi.org/10.29036/jots.v11i20.139

24. Freestone, R. (2007). The Internationalization of the city beautiful. International Planning Studies, 12(1), 21-34. https://doi.org/10.1080/13563470701346527

25. Freixanet, J. (2014). Innovation and internationalization: Relationship and implications for management and public policy. International Journal of Entrepreneurial Knowledge, 2(2), 57-75. https://doi.org/10.1515/ijek-2015-0006

26. Getz, D., \& Page, S. (2016). Progress and prospects for event tourism research. Tourism Management, 52, 593-631. https://doi.org/10.1016/j.tourman.2015.03.007

27. Gomezelj, D. O. (2016). A systematic review of research on innovation in hospitality and tourism. International Journal of Contemporary Hospitality Management, 28(3), 516-558. https://doi.org/10.1108/IJCHM-10-2014-0510

28. Grasso, F. (2014). Local governance, resources and tourism promotion: The case of Taormina. Economics and Sociology, 7(3), 170-178. https://doi.org/10.14254/2071-789X.2014/7-3/13

29. Han, H. (2021). Consumer behavior and environmental sustainability in tourism and hospitality: a review of theories, concepts, and latest research. Journal of Sustainable Tourism, 29(7), 1021 1042. https://doi.org/10.1080/09669582.2021.1903019

30. https://www.amazon.co.uk/s? $=$ internacionaliza $\% \mathrm{C} 3 \% \mathrm{~A} 7 \% \mathrm{C} 3 \% \mathrm{~A} 3 \mathrm{o}+\mathrm{de}+$ destinos + tur $\% \mathrm{C} 3$ $\%$ ADsticos\&i $=$ stripbooks\&ref $=$ nb sb noss

31. Khyareh, M. M., \& Amini, H. (2021). Governance Quality, Entrepreneurship and Economic Growth. Journal of Competitiveness, 13(2), 41-64. https://doi.org/10.7441/joc.2021.02.03

32. Kłysik-Uryszek, A., \& Kuna-Marszałek, A. (2015). Geographical breakdown of Polish OFDI: Explanatory potential of Uppsala model. Journal of International Studies, 8(1), 150-163. https://doi.org/10.14254/2071-8330.2015/8-1/1/13

33. Komorowski, J. W. (2000). Internationality potential factors in Polish cities (1992-1997). Przeglad Geograficzny, 72(4), 429-444.

34. Kuhzady, S., Olya, H., \&Farmaki, A. (2021). Sharing economy in hospitality and tourism: a review and the future pathways. Journal of Hospitality Marketing and Management. https://doi.org/10.1080/19368623.2021.1867281 


\section{JOURNAL OF TOURISM AND SERVICES}

Issue 23, volume 12, ISSN 1804-5650 (Online)

www.jots.cz

35. Liu, N., Xu, Z., \& Skare, M. (2021). The research on COVID-19 and economy from 2019 to 2020: analysis from the perspective of bibliometrics. Oeconomia Copernicana, 12(2), 217-268. https://doi.org/10.24136/oc.2021.009

36. Makkonen, M., \& Rohde, S. (2016). Cross-border regional innovation systems: Conceptual backgrounds, empirical evidence and policy implications. European Planning Studies, 24(9), 16231642. https://doi.org/10.1080/09654313.2016.1184626

37. Makkonen, T., \& Weidenfeld, A. (2016). Knowledge-based urban development of cross-border twin cities. International Journal Knowledge-Based Development, 7(4), 389-406. https://doi.org/10.1504/IJKBD.2016.080881

38. Makkonen, T., \& Williams, A. M. (2016). Border region studies: The structure of an 'offbeat' field of regional studies. Regional Studies, Regional Science, 3(1), 355-367. https://doi.org/10.1080/21681376.2016.1209982

39. Marek, W. (2021). Will the consequences of covid-19 trigger a redefining of the role of transport in the development of sustainable tourism? Sustainability (Switzerland), 13(4), 1887, 1-15, https://doi.org/10.3390/su13041887

40. Mira, M. R., \& Breda, Z., (2019). Internacionalização de destinos turísticos: Uma abordagem sistémica. BeauBassin, Mauritius: Novas Edições Acadêmicas, Omni Scriptum Publishing.

41. Mozzato, A., Grzybovski, D., \& Teixeira, A. (2016). Análises qualitativas nos estudos organizacionais: As vantagens no uso do software NVivo ${ }^{\circledR}$. Revista Alcance, Eletrónica, 23(4), 578 587. https://doi.org/alcance.v23n4.p578-587.

42. Nilsson, J. H., Eskilsson, L., \& Ek, R. (2010). Creating cross-border destinations: Interreg programmes and regionalisation in the Baltic Sea Area. Scandinavian Journal of Hospitality and Tourism, 10(2), 153-172. https://doi.org/10.1080/15022250903561978

43. Onuferová, E., Čabinová, V., \& Dzurov Vargová, T. (2020). Analysis of modern methods for increasing and managing the financial prosperity of businesses in the context of performance: a case study of the tourism sector in Slovakia. Oeconomia Copernicana, 11(1), 95-116. https://doi.org/10.24136/oc.2020.004

44. Pestana, M. H., \& Gageiro, J. N. (2014). Análise de dados para ciências sociais: A complementaridade do SPSS (6 ${ }^{\mathrm{a}}$ ed.). Lisboa: Edições Sílabo.

45. Prokkola, E-K, \& Lois, M. (2016). Scalar politics of border heritage: An examination of the EU's northern and southern border areas. Scandinavian Journal of Hospitality and Tourism, 16, 14-35. https://doi.org/10.1080./15022250.2016.1244505

46. Rovira, N. (2016). ¿Ciudades en el mapa o en la guía turística? Venta de la ciudad y sentido del $\begin{array}{lllll}\text { lugar. Revista } \quad C I D O B & \text { d'Afers } & \text { Internacionals, }\end{array}$ https://doi.org/10.24241/rcai.2016.113.2.89

47. Sakharchuk, E., Kharitonova, T., Krivosheeva, T., \& Ilkevich, S. (2013). The study of the present state and prospects of cultural tourism in the Russian Federation (Exemplifying Moscow Region). World Applied Sciences Journal, 27, 309-314. https://doi.org/10.5829/idosi.wasj.2013.27.elelc.64

48. Sanz-Ibáñez, C., \&Clavé, S. (2016). Strategic coupling evolution and destination upgrading. Annals of Tourism Research, 56, 1-15. https://doi.org/10.1016/i.annals.2015.10.010

49. Sarasa, J. (2015). Mito y estrategias para un destino romántico: La ciudad de Teruel. Cuadernos de Turismo,36, 39-54. https://doi.org/10.6018/turismo.36.230871

50. Scuttari, A., Volgger, M., \& Pechlaner, H. (2016). Transition management towards sustainable mobility in Alpine destinations: Realities and realpolitik in Italy's South Tyrol region. Journal of Sustainable Tourism, 24(3), 463-483. https://doi.org/10.1080/09669582.2015.1136634

51. Sertakova, E., Koptseva, N., Kolesnik, M., Libakova, N., Luzan, V., \& Sergeeva, N. (2016). Brand-management of Siberian cities: Krasnoyarsk as a case study. International Review of Management and Marketing, 6(S5),185-191. 


\section{JOURNAL OF TOURISM AND SERVICES}

Issue 23, volume 12, ISSN 1804-5650 (Online)

www.jots.cz

52. Soares, J., Baidal, J., \& Gândar, J. (2015). La evolución de destinos turísticos litorales consolidados: Análisis comparado de balneario Camboriú (Brasil) y Benidorm (España). Anales de Geografía,35(2), 143-166. doi.org/10.5209/rev AGUC.2015.v35.n2.50118

53. Szytniewski, B., Spierings, B., \& van der Velde, M. (2017). Socio- cultural proximity, daily life and shopping tourism in the Dutch-German border region. Tourism Geographies, 19(1), 63-77. https://doi.org/10.1080/14616688.2016.1233289

54. Timothy, D., Saarinen, J., \& Viken, A. (2016). Editorial: Tourism issues and international borders in the Nordic Region. Scandinavian Journal of Hospitality and Tourism, 16(1), 1-13, https://doi.org/10.1080/15022250.2016.1244504

55. Todd, L., Leask, A., \& Ensor, J. (2017). Understanding primary stakeholders' multiple roles in hallmark event tourism management. Tourism Management, 59, 494-509. https://doi.org/10.1016/j.tourman.2016.09.010

56. Varró, K. (2016). Recognising the emerging transnational spaces and subjectivities of crossborder cooperation: Towards a research agenda. Geopolitics, 21(1), 171-194. https://doi.org/10$\underline{1080 / 14650045.2015 .1094462}$

57. Vermeulen, R. (2015). Pursuing the peripheral path?: A path-dependent analysis of the Frankfurt and Munich fairs. European Planning Studies, 23(2), 332-348. https://doi.org/10.1080/09654313.2013.867318

58. Vinuto, J. (2014). A amostragem em bola de neve na pesquisa qualitativa: Um debate em aberto. Temáticas,22(44), 203-220. https://doi.org/10.20396/tematicas.v22i44.10977

59. Vodeb, K., \& Rudež, H. (2016). Possibilities for inter-destination collaboration in tourism in the case of Opatija and Portorož: A managerial perspective. RevijaZaSociologiju, 46(2), 205-227. https://doi.org/10.5613/rzs.46.2.4

60. Volgger, M., \& Pechlaner, H. (2015). Governing networks in tourism: What have we achieved, what is still to be done and learned?.Tourism Review, 70(4), 298-312. https://doi.org/10.1108/TR$\underline{04-2015-0013}$

61. Weidenfeld, A. (2013). Tourism and cross border regional innovation systems. Annals of Tourism Research,42, 191-213. https://doi.org/org/10.1016/j.annals.2013.01.003

62. Więckowski, M., \&Cerić, D. (2016). Evolving tourism on the Baltic Sea coast: Perspectives on change in the Polish maritime borderland. Scandinavian Journal of Hospitality and Tourism, 16(1), 98111. https://doi.org/10.1080/15022250.2016.1244598

63. Yeoman, I., \& Beeton, S. (2014). The state of tourism futures research: An Asian Pacific ontological perspective. Journal of Travel Research, 53(6), 675-679. https://doi.org/10.1177/0047287514551054

64. Zhang, Y., \& Wang, L. (2020b). Progress in space tourism studies: a systematic literature review. Tourism Recreation Research, https://doi.org/10.1080/02508281.2020.1857522

\section{Brief description of Author/Authors:}

Maria do Rosário Mira, PhD.

ORCID ID: https://orcid.org/0000-0001-8878-955X

SCOPUS Author ID: 57204468916

Web of Science Researcher ID: N-3212-2018

Affiliation: Ph.D in Tourism and Assistant Professor at the Higher School of Education, Polytechnic Institute of Coimbra, Rua D. João III, Solum, 3030-329 Coimbra, Portugal, www.esec.pt

Email: mrmira@esec.pt 
Member at CiTUR - RIPTUR and GOVCOPP-UA. International auditor for UNWTO TEDQUAL Certification Program, for the education in tourism and gastronomy courses. Her research interests relate to the quality, human resources, and internationalization of tourism destinations.

\section{Zélia de Jesus Breda, PhD}

ORCID ID: https://orcid.org/0000-0002-5882-063X.

SCOPUS ID- 36631560700

Affiliation: PhD in Tourism, University of Aveiro (DEGEIT), Campus Universitário de Santiago, 3810 - 193 Aveiro, Tel. + 351234370361 , Fax. + 351234370215.

Email address: zelia@,ua.pt

Assistant Professor at the Department of Economics, Management, Industrial Engineering and Tourism (DEGEIT), University of Aveiro. She is an integrated member of the Research Unit 'Governance, Competitiveness, and Public Policies', a founding member and vice-president of the Observatory of China, and a senior consultant of IDTOUR, a tourism R\&D spin-off company. 